\title{
Article \\ The Tourist Attractiveness of Tokyo in the Opinion of Surveyed Tourists
}

\author{
Michał Roman $1, *\left(\mathbb{D}\right.$ and Katarzyna Bury ${ }^{2}$
}

1 Department of Tourism, Social Communication, and Consulting, Institute of Economics and Finance, Warsaw University of Life Sciences, Nowoursynowska 166, 02-787 Warsaw, Poland

2 Public Relations Student Research Group, The Economic Department, Warsaw University of Life Sciences, 02-787 Warsaw, Poland; burykasia@gmail.com

* Correspondence: michal_roman@sggw.edu.pl

\section{check for}

updates

Citation: Roman, M.; Bury, K. The Tourist Attractiveness of Tokyo in the Opinion of Surveyed Tourists. Tour. Hosp. 2022, 3, 184-209. https:// doi.org/10.3390/tourhosp3010014

Academic Editor: Alexander Hodeck

Received: 10 January 2022

Accepted: 3 February 2022

Published: 9 February 2022

Publisher's Note: MDPI stays neutral with regard to jurisdictional claims in published maps and institutional affiliations.

Copyright: (C) 2022 by the authors. Licensee MDPI, Basel, Switzerland. This article is an open access article distributed under the terms and conditions of the Creative Commons Attribution (CC BY) license (https:// creativecommons.org/licenses/by/ $4.0 /)$.

\begin{abstract}
This article covers the topic of the tourist attractiveness of Tokyo in the opinion of 369 tourists from Poland. A definition of tourist attractiveness and its factors is provided. Basic information on Tokyo, including accommodation, eating facilities, and tourist traffic in the city is offered. The results of the research performed with the use of a survey questionnaire are demonstrated. The research shows that tourists' most appreciated elements of Tokyo's tourist attractiveness are transport accessibility, eating facilities, and cultural assets. The article's hypotheses, that the most attractive seasons in Tokyo, tourism-wise, are spring and autumn, and that the most attractive monument in Tokyo is the oldest Buddhist temple, Sensō-ji, located in the Taitō district, were confirmed to be positive. The third hypothesis was also positively verified. The research shows that younger people positively assessed Tokyo as an attractive and friendly city more than older people.
\end{abstract}

Keywords: tourist attractiveness; evaluation; Tokyo; tourism; tourist assets

\section{Introduction}

Travel is a phenomenon that has accompanied humankind from the beginning of its existence. Initially, man would travel to find the right place to live or to acquire food. Throughout the years, however, travel goals, the distance traveled, and the means of transport have changed. The term "tourism" has appeared, and people have felt the need to get to know new places and cultures. Tourist destinations vary in many ways, which is how the term "tourist attractiveness" emerged and how the factors affecting it were formulated. Now, tourism is an inseparable element of human life and the motivations behind travel vary a lot. Studies have been performed and statistics collected on the most popular tourist destinations across the world. Different countries across the world have noticed that tourism is a very profitable branch of the economy, and so promoting local tourism by developing and launching marketing campaigns has become common. One of the many countries promoting its tourist assets is Japan, which has started its marketing strategy in Poland. More and more tourists have begun to perceive Japan as a future tourist destination, and the first place visited in Japan is often Tokyo.

This article aims at investigating Tokyo's tourist attractiveness and presenting the opinions of tourists on the city as a tourist destination. The article's topic is important in terms of changing trends in tourism and the growing tourist awareness of even such distant parts of the world as Tokyo.

Tokyo, the name of which means "eastern capital", is a city on the south-eastern coast of the island of Honshu. It has a population of about nine million [1]. According to the Statista Internet portal, in 2019 the city was visited by 15.2 million foreign tourists [2].

The authors selected the topic of the article, "Tourist attractiveness of Tokyo in the opinion of tourists", because they consider Tokyo one of the more interesting and less obvious tourist destinations, where tourists can experience how huge the cultural differences in 
various parts of the world are. Tokyo, as the capital of Japan, is the number one top-visited place by tourists coming to the country. In this city, one can note an ideal combination of the latest technologies intermingled with Japanese tradition and architecture. The "eastern capital" offers many tourist attractions, both cultural and natural, which vary a lot and are very attractive. Tokyo is a very modern place where, at seemingly every single moment, new buildings and brand-new technological solutions are emerging. The Tokyo transport system is almost perfectly reliable, thanks to which one can move from point $A$ to $B$ with no problem whatsoever. People residing in this metropolis are very attentive to law and order; as a result, the city is very clean and one can hardly spot any rubbish in the streets. Despite many difficulties due to frequent natural disasters occurring in the city, Tokyo keeps on developing in terms of tourism. Year by year, a growing number of tourists choose it as their travel destination.

According to the authors, Tokyo enjoys a very high tourist potential, which, when used well, could make it one of the most frequently visited cities globally. Every year, tourists become more and more open to getting to know different cultures and searching for less obvious tourist destinations, and Tokyo is, indeed, one such destination.

The article has been supported by existing tourist attractiveness studies, especially by Z. Kruczek, I. Bakk, and M. Matlegiewicz; I. M. Batyk, A. Rapacz, and D. E. Jaremen; A. Kowalczyk; and M. Preisler. The information on tourism in Tokyo, on the other hand, was supported by reports by, e.g., K. Sonnenberg, K. Dopierała, S. Guichard-Anguis, O. Moon, K. Drew, R. Hallett, O. Lee, M. Zatko, J. Henderson, H. Zhang, F. Xu, L. Lin, Y. Lei, J. Saito, and K. Matsui.

\section{The Essence of Tourist Attractiveness in a Literature Review}

\subsection{The Term "Tourist Attractiveness"}

The term "tourist attractiveness" cannot be univocally defined. The applicable literature notes that tourist attractiveness is a relative term, as one must consider a variety of forms and types of tourism. While applying that term, it is, therefore, necessary to formulate what specific form of tourism the attractiveness refers to [3].

Interestingly, the tourist attractiveness of a given place can be experienced differently by tourists than by entrepreneurs of the tourism industry. It also depends on the existing development and development potential of tourism in a given place [4].

Tourist attractiveness can have three different meanings, which can be specified in the following way [5]:

- Tourist attractiveness is subjectively considered; a specific place can be considered in terms of tourist attractiveness based on one's own experience and world view;

- Tourist attractiveness is considered as a result of standardization and categorization;

- Tourist attractiveness is considered valorization, applying a given research technique.

Due to the said diversity in the way tourism attractiveness is perceived, the authors have decided to break down a few definitions of the term found in the applicable literature. The idea is to investigate similarities and differences in the way different authors perceive the term tourist attractiveness. Respective definitions are provided in Table 1. 
Table 1. Definition of tourist attractiveness according to the selected Polish authors.

\begin{tabular}{|c|c|}
\hline Author, Year of Publication & Definition \\
\hline Kruczek, 2011 [6] & $\begin{array}{l}\text { Tourist attractiveness is a complex term and it must be comprehensively considered. It is } \\
\text { determined by tourist attractions, transport availability, and the supply of the services related to } \\
\text { the visited areas' management services. } \\
\text { It is, therefore, a term that integrates elements providing a springboard for tourist traffic } \\
\text { development, namely tourist attractions with the conditions of how to satisfy the needs of that } \\
\text { traffic with the adequately developed tourist infrastructure. }\end{array}$ \\
\hline Batyk, 2010 [7] & $\begin{array}{l}\text { Tourist infrastructure is seen from the occurrence of a unique feature, to a certain extent, } \\
\text { attracting a specific kind of tourism to be considered in a comprehensive manner. The feature can } \\
\text { include both the qualities of the natural landscape and cultural assets. }\end{array}$ \\
\hline Bąk, Matlegiewicz, 2010 [8] & $\begin{array}{c}\text { The region's tourist attractiveness is considered a property with a specific set of natural or } \\
\text { non-natural features that are of interest to tourists. Tourist attractiveness is a subjective } \\
\text { experience. It is not always the case that the geographic, social or cultural environment is an } \\
\text { attraction for the tourist. }\end{array}$ \\
\hline Rapacz, Jaremen, 2011 [9] & $\begin{array}{l}\text { Tourist attractiveness is a complex term, not always univocal. It can be an area, region, tourist } \\
\text { destination, or a specific structure that can be attractive in terms of tourism. The tourist } \\
\text { attractiveness of the regions and tourist structures is determined, on the one hand, by objective } \\
\text { factors, e.g., the occurrence of nature qualities, human impact qualities, or adequate elements of } \\
\text { tourist infrastructure and tourism-related services. On the other hand, the attractiveness of a } \\
\text { specific place is determined by a subjective perception of all those factors by tourists, investors, } \\
\text { and residents. }\end{array}$ \\
\hline
\end{tabular}

Source: [6-9].

The above definitions suggest that the authors agree that the term tourist attractiveness cannot be univocally defined and that each tourist arriving at a given destination can consider its attractiveness differently. Some places can be attractive for one tourist but not for another, as it depends on what the tourist arriving at one destination expects in a specific place. The definitions also provide information that tourist attractiveness is made up of some factors which affect it.

\subsection{Factors Affecting Tourist Attractiveness}

Tourist attractiveness determines the extent to which a given destination, structure, or phenomenon encourages tourists to come over, and includes a few factors [10].

Tourist qualities are one of the key factors of the region's tourist attractiveness. The term includes such elements as a set of natural assets, those shaped by history and those created by contemporary times. Of the tourist qualities, we can differentiate:

- Leisure qualities;

- $\quad$ Nature qualities;

- Cultural qualities;

- Specialist qualities.

Tourist management (tourist infrastructure), including tourist equipment, facilitates leisure tourists to enjoy the assets of the destination of their choice. Tourist infrastructure can be broken down into two groups:

- Technical infrastructure (e.g., food and accommodation facilities);

- Social infrastructure (e.g., service offices, tourist information centres).

Transport availability stimulates the development of tourism. It is a very important aspect of tourist attractiveness, since an insufficient development of the means of transport makes tourism impossible or inhibits its development.

More and more frequently, in addition to all the above factors of tourist attractiveness, there is another: natural environment pollution. Tourists are more and more attracted to destinations that can offer a clean environment and access to nature. 


\subsection{Tourist Attractiveness of the Cities}

Cities have continuously been the primary tourist destination. A tourist who comes for the first time to a given country, in general, stays in the city. The initial city travel destinations were connected with trade and politics, and only later did people start to come to the cities for leisure and to learn more. Tourism is an essential factor of city development as it triggered the development of the hotel and food-serving industries, and historic sites were made available to tourists for sightseeing. Moreover, the development of tourist guides was launched to make specific cities attractive in terms of tourism closer to tourists [11].

The tourist attractiveness of cities has very fast become a subject of scientific research. In their studies, researchers have made attempts at specifying the factors which affect the tourist attractiveness of a given city. It is starting to be believed that the tendency towards change from the principle "3S" (Sea, Sun, Sand) to the principle "3E" (Entertainment, Excitement, Education) is very much observable in city tourism, since tourists, during their trips, more and more often are interested in sports, entertainment, visiting a famous restaurant, cafes or going shopping [12]. In terms of tourist attractiveness, the principle referred to as "4A" (Attractions, Amenities, Accommodation, Access) is starting to be applied, although, according to H. Hughes, "4A" should also include "Atmosphere" [13].

In his elaboration "Nowe formy turystyki miejskiej", A. Kowalczyk uses a diagram to show what factors make up a city's tourist attractiveness [13] (Figure 1).

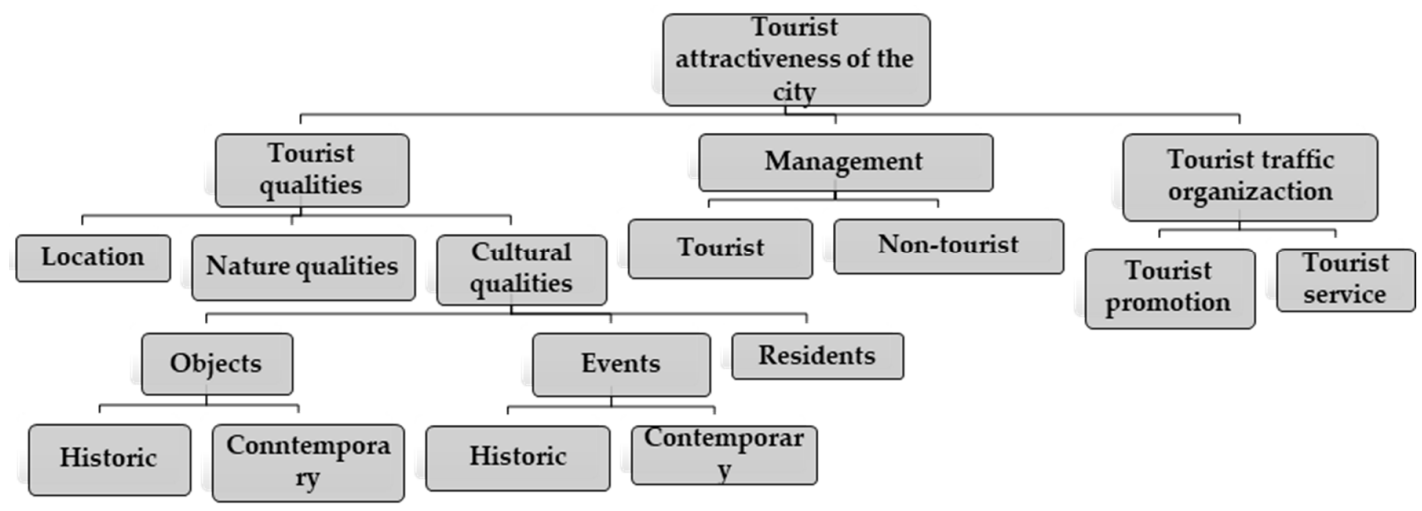

Figure 1. Factors making up a city's tourist attractiveness. Source: [13].

It used to be believed that the tourist attractiveness of a city mostly depends on tourist attractiveness and tourist management; however, at present it is believed that an essential factor that also affects the attractiveness of a given city is the tourist traffic organization system. Its key elements are tourism promotion and tourist services [14].

In the article "Uwarunkowania atrakcyjności turystycznej miasta" by M. Preisler, one can note that the author breaks down the conditions affecting the level of attractiveness of a city into two categories, namely [11]:

- External conditions;

- Internal conditions.

Both the external and internal conditions intermingle and create a homogenous entity referred to as the atmosphere of the city. The atmosphere of the city has a huge impact on the development of tourism.

\section{Tourist Attractiveness of Tokyo}

3.1. Characteristics of Tokyo and the Development of Tourism in the City in Recent Years 3.1.1. Basic Information on Tokyo

Tokyo is located in the mouth of the Sumida River to Tokyo Bay, in the southern part of the Kantō region, found on Honsiu island, the biggest island of Japan. In terms of its area, Tokyo is difficult to define. Very often it is provided with three different names [15]: 
The Greater Tokyo Area or the Tokyo Megalopolis Region, which consists of Tokyo and three neighbouring prefectures: Saitama, Chiba, and Kanagawa. The Greater Tokyo Area is home to about $30 \%$ of the population of the entirety of Japan and possesses the world's biggest city agglomeration, with a population of 37.3 million [16].

The Tokyo Metropolis Region (Tokyo Prefecture), which consists of 23 special wards, including the Tama region in the western part of the prefecture, is made up of 39 communes and the archipelagos of Izu islands and Ogasawara islands, inscribed on the UNESCO World Heritage List in 2011. The area is $2190 \mathrm{~km}^{2}$ [17]. It is populated by almost 13.9 million people [18].

The city itself, Tokyo, which is made up of 23 special wards, and is populated by about 9 million people [1].

In the 15th century, Tokyo was a small fisherman's village which, later in the era of the shogunate, upon the decision of the Edo clan, was surrounded by fortifications. The town was given the name Edo. Almost a century later, Edo became the seat of Ieyasu Tokugawa. He was the first shogun of the family who ruled Japan for almost three successive centuries. Under his rule, Edo was developed intensively. It is claimed that by the 18th century Edo was already one of the biggest cities globally in terms of population. In 1853 on the shore of Japan there appeared American ships commanded by Commodore Matthew C. Perry. Upon his order, there were opened two harbours in Japan to develop international trade. The demand for foreign goods caused prices to increase and inflation to kick in. As a consequence, there were mass strikes, used by the supporters of young Emperor Mutsuhito. He left Kyoto and arrived in Edo, where he standardized the authority and changed the name of the new capital of the country to Tokyo. Tokyo was developing vibrantly and, at the beginning of the 20th century, its population was already over 2 million. Unfortunately, on 1 September 1923, the city suffered a great earthquake, which triggered vast fires. As a result, about 140 thousand people lost their lives. During WWII, Tokyo suffered successive huge destruction during many American bombings. However, after WWII all residents of Tokyo were engaged in the reconstruction of the city and its glory was fast regained. Today, Tokyo is a global business centres and a city that keeps developing [1].

\subsubsection{Accommodation in Tokyo}

Accommodation stands for all kinds of structures and facilities thanks to which the tourist can stay overnight outside their regular place of residence [19]. Accommodation is one of the elements of tourist management.

Tokyo is well developed in terms of accommodation. The variety of accommodation facilities in the city is huge enough that each and every tourist finds a place to meet their requirements and needs. The prices offered by accommodation facilities vary a lot and, to a large extent, depend on the location of a given building, its kind, and the amenities it offers to guests. The facilities can be divided into [20]:

- City hotels;

- Business hotels;

- Resorts;

- Capsule hotels;

- Hostels;

- Ryokan;

- Minshuku;

- Shukubo;

- Private apartments;

- Accommodation in facilities rented from private persons (e.g., by Airbnb);

- Share houses.

\section{Capsule Hotel}

In Japan, there operate capsule hotels, very often found in Tokyo. They can usually be found next to railway stations. They provide very many small cabins where the entire area 
is occupied by a Japanese mattress; a futon. In general, one cabin can usually be occupied by one person only. In most of them, one will find bedding, blankets, pillows, lamps, alarm clocks and a tv set, and a radio built-in the wall. In such facilities bathrooms are part of the shared area. The hotels are very cheap and, by definition, they were meant only for men; however, many of them started welcoming women as well and offering a division of the stories or buildings between the sexes. The capsule hotels are also very popular with foreign tourists and so most of them offer English-speaking websites and booking systems [21].

Ryokan

Ryokan is a kind of traditional Japanese inn, which provides the guests with a unique experience of getting to know amazing Japanese traditions. Ryokan is one of the few places where tourists can experience the Japanese culture in a comprehensive manner. The rooms in the ryokan are decorated with flower arrangements and in the room recesses, known as tokonoma, scrolls of calligraphy are hung. In ryokan, one can also experience the Japanese ceremony of tea brewing by a woman wearing traditional Japanese clothes known as kimono. The ryokan floors are covered with traditional Japanese mats, tatami, and the bed is replaced with a mattress known as a futon. Such accommodation facilities also provide a shared bathroom and the guests can wear traditional Japanese clothes known as yukata and taste local Japanese cuisine [22].

\section{Minshuku}

Minshuku are B\&B (Bed and Breakfast)-type accommodation facilities ran by Japanese families. They are usually found in the close vicinity of hot springs, skiing resorts, or mountains. Minshuku are small buildings, which usually offer only a few guest rooms. Similar to ryokan, in minshuku, the guests are offered a room covered with tatami and a traditional Japanese mat, a futon. The room amenities usually include a small TV set, a little table, a heater, a tea-brewing set, and towels. Such accommodation facilities are an ideal solution for tourists who want to experience a traditional Japanese lifestyle thanks to living with a Japanese family [23].

Shukubo

A wooden building, shukubo, is a kind of accommodation facility that is part of a Japanese temple. It is a type of accommodation where the tourist can experience the surrounding history and culture of Japan. The temples are provided with gardens that are part of Japanese art and which show the beauty of changing seasons. They also show a spirit of harmony with nature. Japanese temples serve vegetarian cuisine known as shojin. It is a cuisine without fish and meat. The grounds for shojin cuisine are to obtain the most flavour from the dish with the fewest spices. It is also important not to waste food. The guests staying in shukubo should obey and respect the principles applicable in the temple [24].

The Bureau of Industrial and Labour Affairs of the Tokyo Metropolitan Government carried out studies on the occupancy rate of the accommodation facilities in Tokyo in 2017. The studies were published in a file known as "Tourist statistics" (Figure 2). 


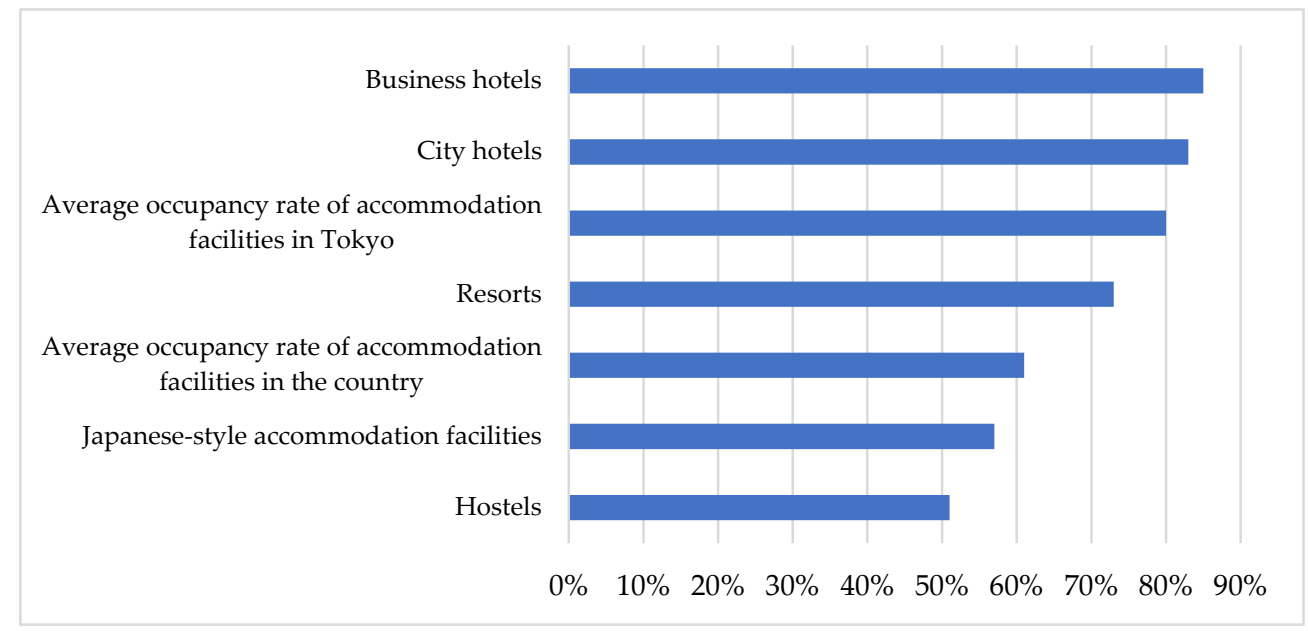

Figure 2. Percentage occupancy rate for the accommodation facilities in Tokyo in 2017 by type (\%). Source: [25].

The figure above shows that the biggest occupancy rate in 2017 in Tokyo was recorded for business hotels where for the whole year more than $4 / 5$ hotel rooms were occupied. A slightly lower occupancy rate than the business hotels was reported for city hotels by city. The lowest occupancy rate was noted for hostels where only half of the hotel rooms were occupied in 2017. On average, in Tokyo, 4/5 of all rooms were occupied.

According to the study by the Japanese Travel Agency, the top occupancy rate of the accommodation facilities in Tokyo in 2019 accounted for 79.7\%, thus causing Tokyo to rank top of all the cities in Japan [26].

\subsubsection{Food-Serving Facilities in Tokyo}

The basic need of the traveller and of each person is to satisfy thirst and hunger, and so a strongly related aspect of tourism development is a food-serving development. Over recent years, people have started to notice that gastronomy is not just a service sector to satisfy physiological needs but also to meet higher-order needs. An example of such needs is a willingness to experience other cultures or get to know "new flavours" [27].

Japanese cuisine plays a crucial role in the development of tourism and culinary motivation is more and more frequently the key reason for those travelling to the country of cherry blossoms. Tokyo varies a lot in terms of eating places. One can find here places serving local and regional Japanese cuisine as well as all kinds of cuisine from other parts of the world [28]. One can also find that traditional Japanese cuisine is known as washoku, due to the importance of the selection of possibly the best ingredients and its diversity, and in 2014 was inscribed on the UNESCO World Heritage List [29].

Interestingly, in Tokyo, there are the world's most restaurants awarded with Michelin stars, the greatest honour an eating place can receive. In the city there operate 167 restaurants with one star awarded, 48 restaurants distinguished with two stars, and 11 restaurants with three stars. In total, in Tokyo there are 226 eating facilities awarded with Michelin stars [30].

Japanese cuisine also has unique flavours that it is famous for. In spring, one can, for example, taste many sweets and beverages that are sakura in flavour, which is the flavour of Japanese cherry. A very popular flavour in Japan is also the flavour of Japanese green tea, matcha, famous all across the world due to its health-boosting properties, which is an additive to many desserts and beverages. Travelling to Tokyo, tourists can be also surprised with a quite atypical additive, found in many sweet dishes: anko. Anko is a sweet paste made from red beans, azuki, and sugar. Interestingly, Japanese cuisine is considered one of the world's best cuisines, also thanks to the umami flavour which, in 2000, was separated as the fifth taste sensed by the man [31]. 
According to the Tabelog site, the biggest Japanese restaurant guide, in Tokyo, in 2019 , there operated 137,186 restaurants, thus meaning the city comes first in terms of the number of restaurants across all of Japan. The Metropolitan Government in Tokyo has also published statistics showing one restaurant for every 101 people in Tokyo (with a population of 13.9 million people) [32].

The study by the Bureau of Industrial and Labour Affairs of the Tokyo Metropolitan Government provides statistics about the most frequent activities of foreign tourists coming to Tokyo in 2017 (Figure 3).

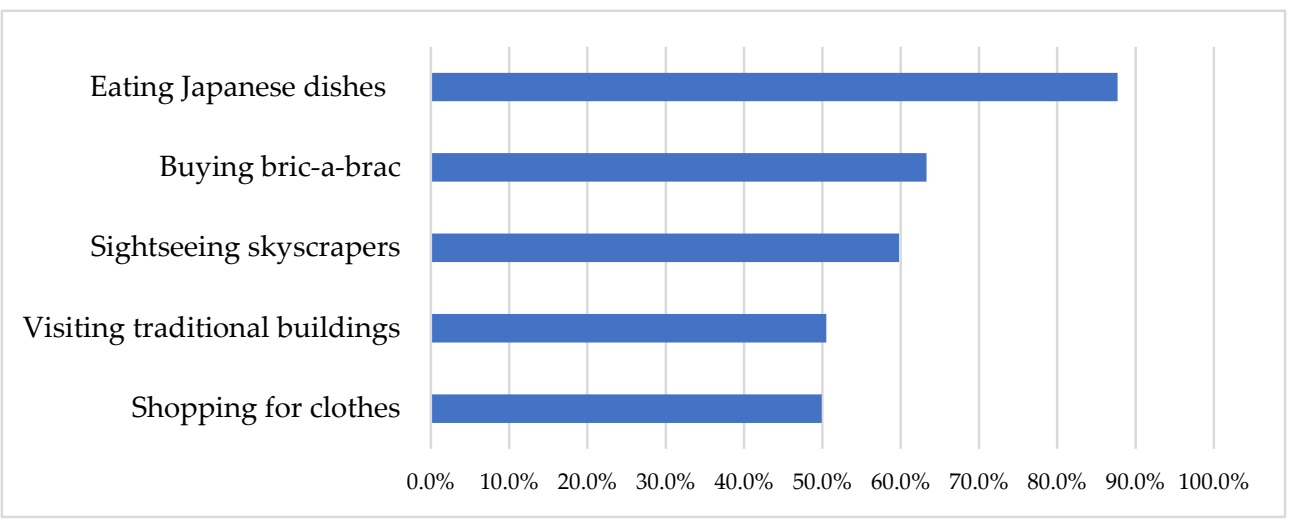

Figure 3. Activities most frequently taken up by foreign tourists in Tokyo in 2017 (\%). Source: [33].

The above figure clearly shows that the most frequent activity taken up by foreign tourists in Tokyo was eating Japanese dishes. One can, therefore, state that Japanese cuisine is one of the factors which very much attracts tourists to the place, and culinary tourism becomes one of the dominant kinds of tourism in this city.

\subsubsection{Tourism in Tokyo}

More and more tourists are deciding to choose Tokyo as their destination, which has made the tourist traffic in the "eastern capital" develop over the last decades. In the figure below one can observe how the number of foreign tourists who visited Tokyo in 2010-2019 was changing (Figure 4).

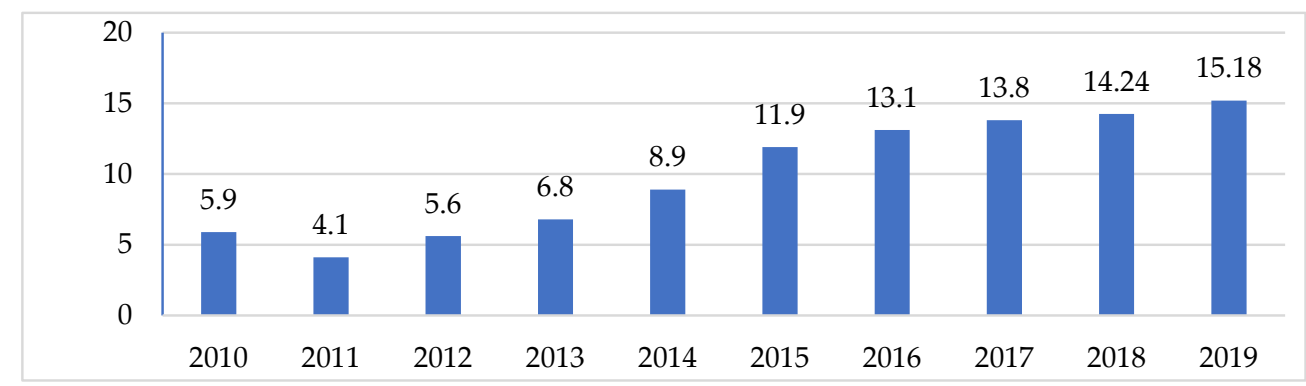

Figure 4. Number of foreign tourists in Tokyo in 2010-2019 (number of tourists in millions). Source: [34].

Analysing the figure, one can note that the biggest value was recorded in 2019, when Tokyo was visited by 15.2 million foreign tourists. In 2011, however, the value was lowest due to a huge earthquake in Tōhoku and a tsunami. The earthquake magnitude in 2011 in Japan was 9 on the Richter scale; it was, therefore, the biggest earthquake recorded in Japan, and its effects were catastrophic. The tsunami, which was created by the earthquake, led to a breakdown in the Fukushima nuclear power plant [35]. All the factors triggered by the earthquake made foreign tourists unwilling to come to Tokyo as they were "terrified" [36].

However, in successive years, the number of foreign tourists started to grow rapidly, owing to the efforts of the Japanese government to promote tourism in the country [37]. 
An example of such efforts is the program "Cool Japan", launched by the Japanese Ministry of Economy, Trade, and Industry, the responsibility of which is the interest of the Western customer in Japan by promoting attractions for them, especially culture, fashion, culinary art, tourism or music [38]. The strategy uses the so-called soft power concept, which stands for a capacity for influencing others by using funds for defining actions, persuasion, and acquiring positive attractiveness to ensure positive results. Of all the countries of Eastern Asia, it is the soft power of Japan that is the strongest and the most perceptible, as can be seen from the number of Japanese restaurants, language schools offering the Japanese language and the number of fans of anime, manga, Japanese music and films, which are also plenty in Poland [39].

Another example of the efforts of the Japanese government to promote tourism is the campaign "Japan-Where tradition meets the future". The campaign was launched on 7 November 2016 and its job is to encourage European tourists to come to Japan. In Japan, to increase the tourist demand, advertisements are created to be posted on social media, on TV, on the means of public transport, or in cinemas [40]. The campaign is targeted at 15 European countries, including Poland [41]. To produce a promotional film, as the main element of the campaign, a German filmmaker was selected [42]. He became famous thanks to his film “In Japan-2015" [43].

\section{Materials and Methods}

The primary objective of the article is to present the tourist attractiveness of Tokyo from a literature review and from the opinion of tourists from Poland who have visited the city at least once. Additionally, the article presents the following goals:

- Getting to know the basic information of Tokyo;

- Presenting the accommodation facilities and eating places in Tokyo;

- Presenting the key tourist attractions of Tokyo;

- Designing a study to include the people who have visited Tokyo;

- Study results presentation and interpretation.

The hypotheses defined by the authors of the article are as follows:

- The most attractive seasons of the year in Tokyo in terms of tourism are spring and autumn;

- The most attractive monument in Tokyo is the oldest Buddhist Sensō-ji temple, located in the Taitō district;

- Younger tourists rated Tokyo more highly than the elderly.

To verify the hypotheses, a diagnostic survey was used, otherwise referred to as polling. The survey questionnaire was developed by the authors of the article and given to the respondents with the use of social media (Facebook type). The survey questionnaire was created using an expert method. Experts (professors from four Polish universities) checked the questionnaire and offered their comments. Initial research was carried out first. The study was performed from 30 January to 15 February 2021. The survey included 23 questions, including 5 demographics. A total of 369 completed survey questionnaire copies were received. The study facilitated determining whether Tokyo is a place attractive for tourists and what factors and places determine that attractiveness.

The subject of the authors' study was tourists who have visited Tokyo at least once. The characteristics of the group of people under study are provided in Table 2. 
Table 2. Social and demographic characteristics of the persons under study.

\begin{tabular}{|c|c|c|}
\hline \multirow{2}{*}{ Specification } & \multicolumn{2}{|c|}{ Total } \\
\hline & $N=369$ & $\%$ \\
\hline \multicolumn{3}{|l|}{ Sex: } \\
\hline - Woman & 255 & 69.1 \\
\hline - Man & 114 & 30.9 \\
\hline \multicolumn{3}{|l|}{ Age: } \\
\hline - Below 18 years of age & 2 & 0.6 \\
\hline - $\quad 18-30$ years of age & 187 & 50.7 \\
\hline - $\quad 31-40$ years of age & 97 & 26.3 \\
\hline - $\quad 41-50$ & 54 & 14.6 \\
\hline - $\quad 51-60$ & 19 & 5.1 \\
\hline - $\quad 61$ and more & 10 & 2.7 \\
\hline \multicolumn{3}{|l|}{ Education: } \\
\hline - $\quad$ Primary & 4 & 1.1 \\
\hline - Vocational & 2 & 0.5 \\
\hline - Secondary school & 73 & 19.8 \\
\hline - Higher & 290 & 78.6 \\
\hline \multicolumn{3}{|l|}{ Professional situation: } \\
\hline - School student & 8 & 2.2 \\
\hline - Higher education student & 44 & 11.9 \\
\hline - I study and work & 39 & 10.6 \\
\hline - White-collar worker & 226 & 61.2 \\
\hline - $\quad$ Blue-collar worker & 26 & 7 \\
\hline • Unemployed & 17 & 4.7 \\
\hline - Old-age pensioner/disabled pensioner & 9 & 2.4 \\
\hline \multicolumn{3}{|l|}{ Place of residence: } \\
\hline - $\quad$ Countryside & 32 & 8.7 \\
\hline - $\quad$ Town with a population of up to 50 thousand & 45 & 12.2 \\
\hline - Town with a population from 50 thousand to 100 thousand & 25 & 6.8 \\
\hline - City with a population from 100 thousand to 500 thousand & 73 & 19.7 \\
\hline - $\quad$ City with a population of above 500 thousand & 194 & 52.6 \\
\hline
\end{tabular}

The study involved more women than men. Around half of the respondents were persons aged 18 to 30 and over $1 / 4$ of the respondents fell within the age range of 31-40. Over $3 / 4$ of the study participants had a higher education background. The lowest number of respondents declared having completed secondary education (4 people) and vocational education ( 2 persons). On average, $2 / 3$ of the participants in the study defined their professional situation as white collar. More than half of the respondents resided in cities with a population above 500 thousand. It can be claimed, therefore, that it was most often the people with higher education who worked as white collars and lived in big cities who travelled to Tokyo. This could have been due to the fact that such people can be more open to getting to know new, different cultures and distant corners of the world.

\section{Results}

5.1. Motivations and Factors Affecting the Organization of Tourist Trips to Tokyo

The study considers the frequency of visits of the respondents to Tokyo. The following choices were available: once, twice, more than twice (Figure 5). 


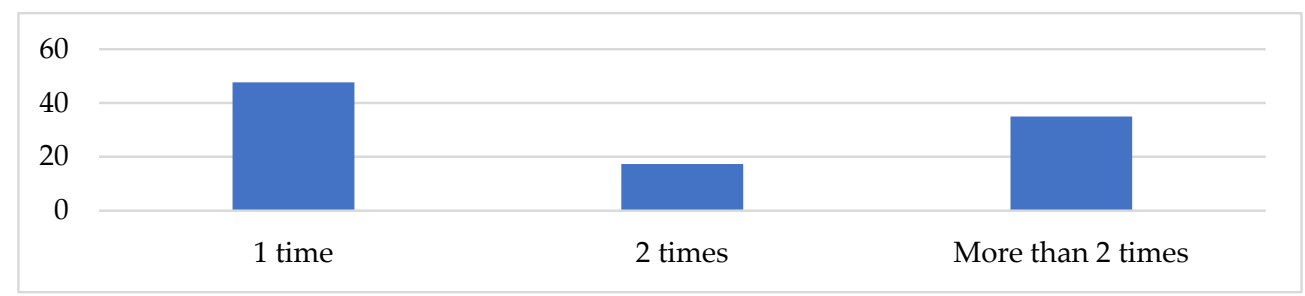

Figure 5. Number of the respondents' trips to Tokyo (\%).

The above figure shows that most of the respondents visited Tokyo once. More than $1 / 3$ of the respondents visited Tokyo more than twice, and about $17 \%$ of the respondents-twice.

The respondents could determine whether they would visit Tokyo again. There were two responses to choose from: yes, no. If the respondent selected the answer "no", he or she could justify his or her choice (Figure 6).

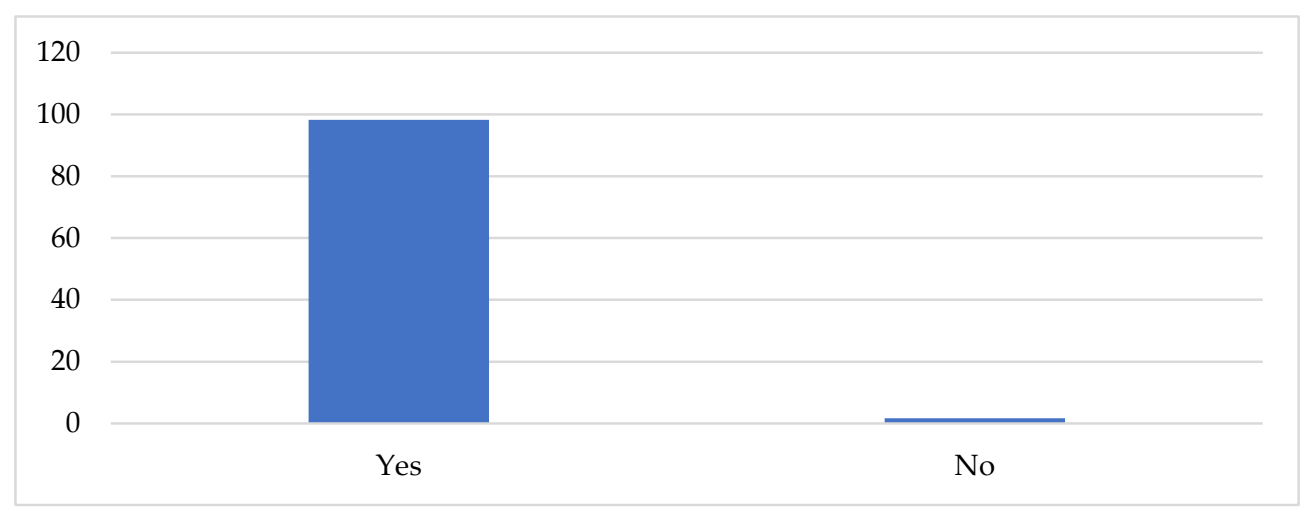

Figure 6. Declaration of willingness to visit Tokyo again (\%).

Almost all the respondents claimed that they would visit Tokyo again. The persons who marked the answer "no" justified their choice with a few arguments, e.g., that they preferred to spend time sightseeing other places or that they had already been to Tokyo a sufficient number of times. One can thus state that Tokyo is a place attractive enough that almost all the respondents would eagerly come back there again.

Another important aspect covered in the survey questionnaire was the length of the persons' stay in Tokyo. Figure 7 presents detailed data.

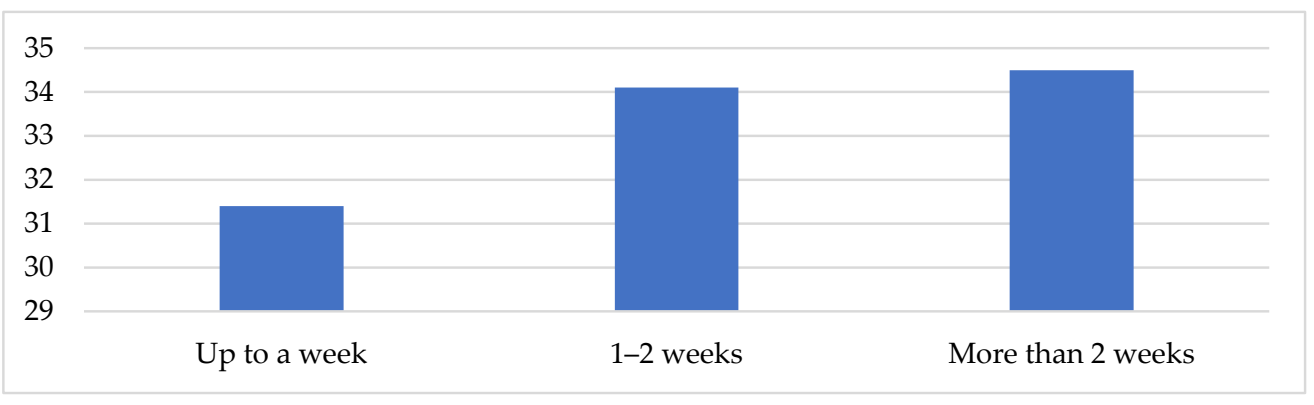

Figure 7. Length of the respondents' stay in Tokyo (\%).

As for that question, the discrepancy was not big and the results were very similar. However, most of the respondents noted that they had been in Tokyo longer than 2 weeks and the lowest number of people declared that their stay in Tokyo had been up to one week. One can thus claim that during travel to such a distant place as Tokyo, the longest stay pays off best, at least due to the price of the air tickets and the length of the travel.

The respondents were also asked to express their opinion on how much time is needed to visit Tokyo. Figure 8 presents detailed data. 


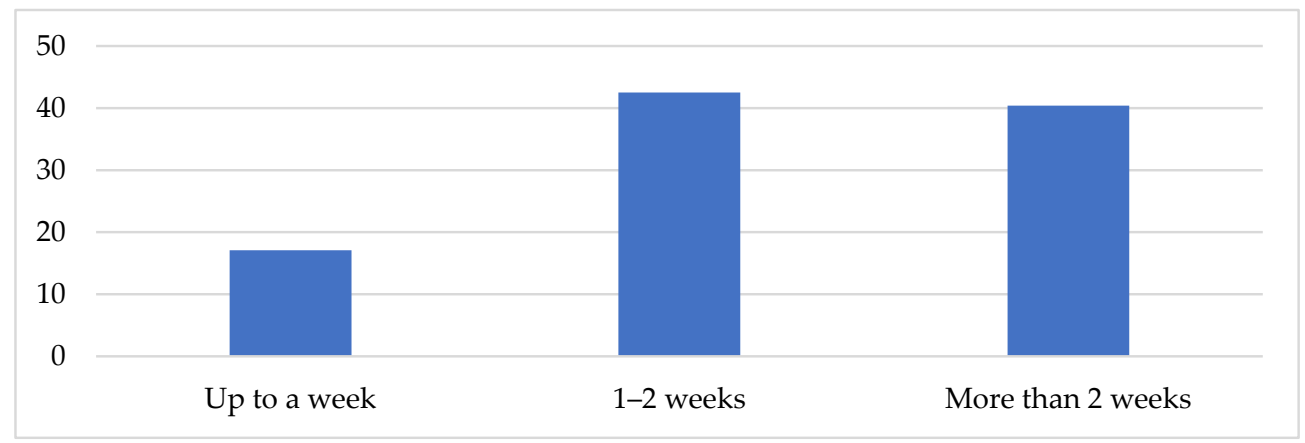

Figure 8. Estimated time required for Tokyo sightseeing according to the respondents (\%).

As seen in the above figure, most respondents said that, in their opinion, sightseeing in Tokyo requires 1-2 weeks. A similar result was recorded for the answer that sightseeing in Tokyo needs more than 2 weeks. The lowest number of respondents marked that less than one week would be enough for sightseeing in that city. The results for that question demonstrate that Tokyo is an interesting city and has enough tourist attractions and that the tourists would like to stay more than one week for sightseeing.

One of the organizational aspects of the trip covered in the study was also the selection of trip companions (Figure 9).

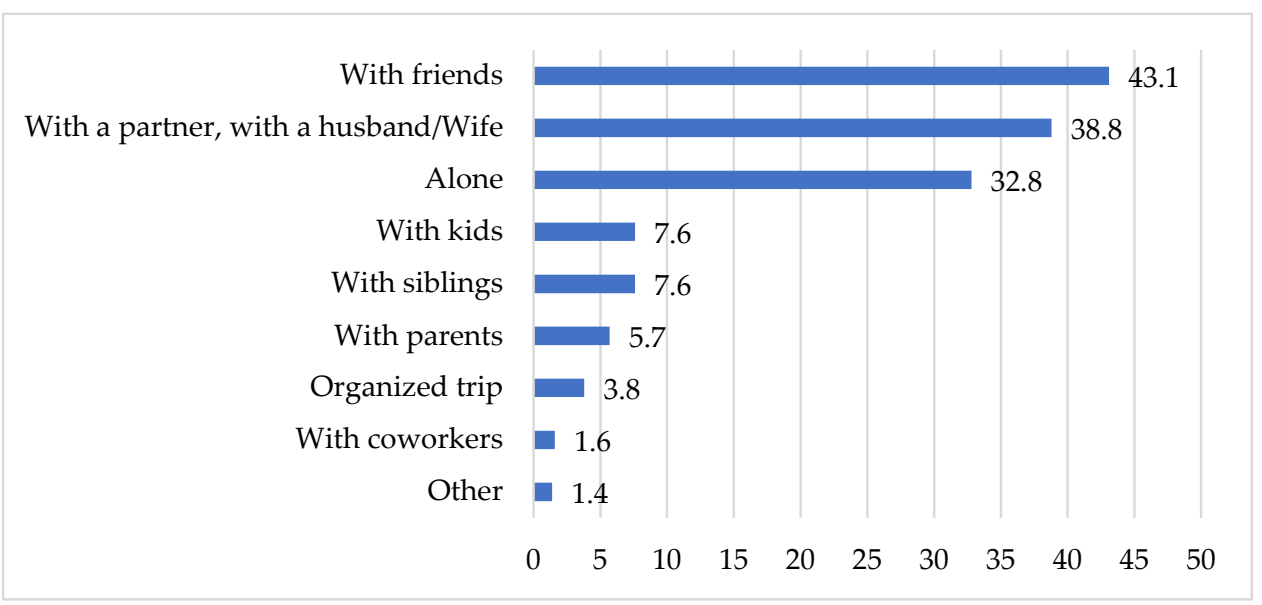

Figure 9. Respondents' trip companions (\%). The respondent could mark more than one answer.

Most frequently, the persons under study travelled to Tokyo with friends, however, the same frequency declared that their trip companions were their partner or a spouse. Surprisingly, a small percentage of people travelled to Tokyo on a package tour. One can conclude from it that Tokyo is a tourist destination of little popularity with package tour organizers and that persons travelling to Tokyo prefer to organize their trip themselves.

The respondents could indicate their key motivations behind going to Tokyo. It was a multiple-choice question and the respondents could also specify their own motivations (Figure 10). 


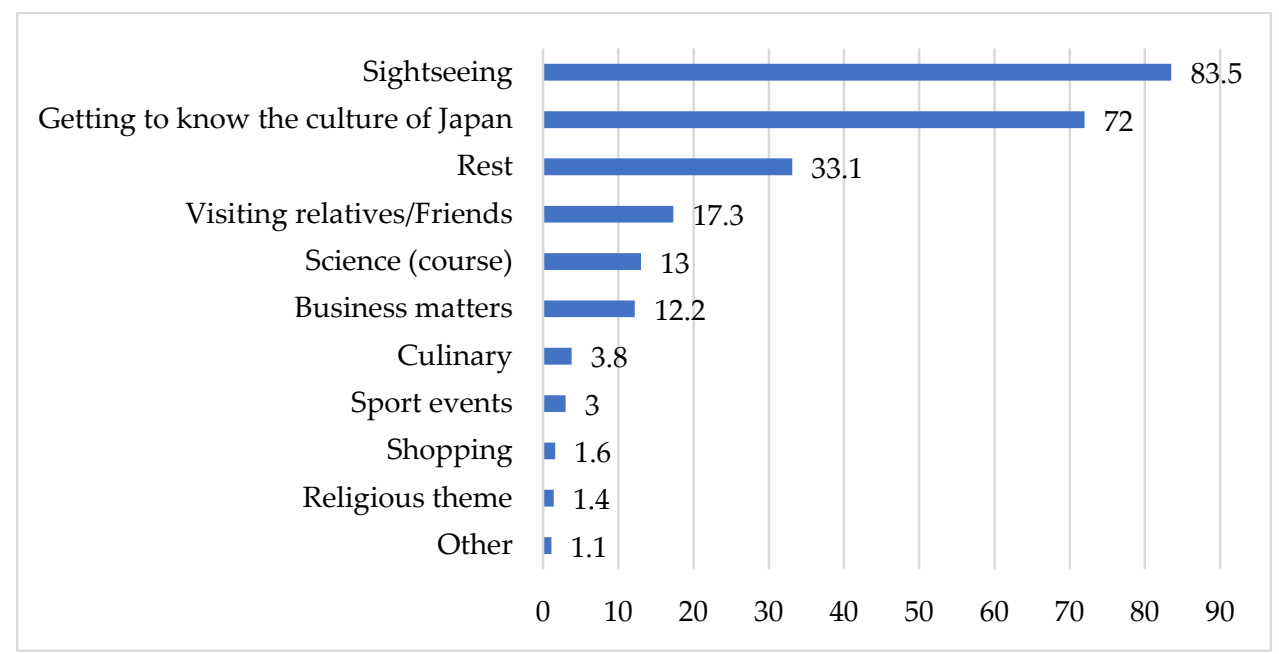

Figure 10. Key motivations behind the respondents' visits to Tokyo (\%). The respondent could indicate more than one response.

One can note that, most often, the respondents chose sightseeing or getting to know the Japanese culture. Every third respondent answered that their motivation behind coming to Tokyo was to have a rest. The least frequent reasons were religion and coming to shop. Analysing the results, one can claim that Tokyo attracts tourists mostly with its variation in nature and cultural qualities and with the interesting culture of Japan.

The respondents could also indicate what accommodation facilities they used during their stay in Tokyo (Figure 11).

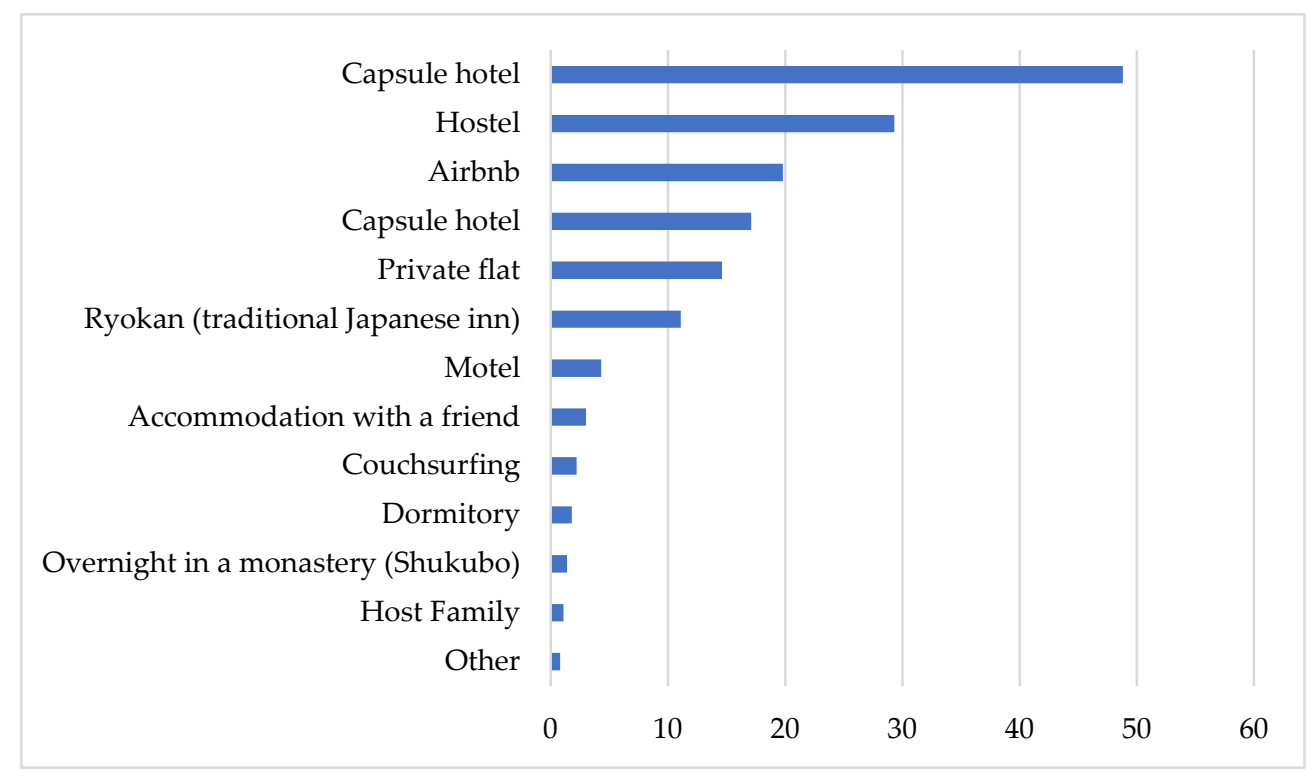

Figure 11. Accommodation selected by the respondents (\%). The respondent could indicate more than one answer.

The above figure shows that almost every second respondent during their stay in Tokyo used hotel services. An interesting result provided by the figure is the fact that almost every third respondent selected hostel accommodation where, in the earlier accommodation analysis in Tokyo, according to the Bureau of Industrial and Labour Affairs of the Tokyo Metropolitan Government, the hostels recorded the lowest occupancy rate in the city. The least frequent responses were the monastery accommodation (Shukubo) and with the socalled host family, namely accommodation with a Japanese host family. This may have 
resulted from the little popularity of the accommodation facilities or a fear of the language barrier, as the hosts might not speak English.

An equally important aspect was the way the trip was organized. The respondents answered whether they organized the trip alone or used travel agency services (Figure 12).

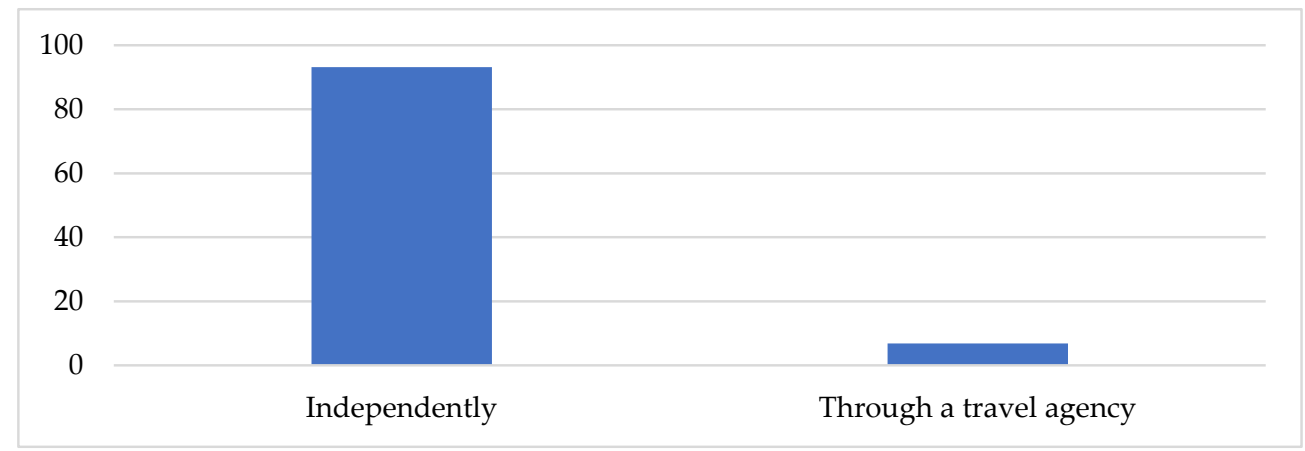

Figure 12. Trip organization by the respondents (\%).

The figure shows that a vast majority of the respondents decided to organize the trip themselves, which can suggest that Tokyo is not a popular tourist destination in travel agencies or that it pays off more to organize a trip to Tokyo yourself.

5.2. Evaluation of Tourist Attractiveness of Tokyo and the Barriers Making Trips to the City Difficult

The respondents also evaluated in what season of the year Tokyo is most attractive for tourists. The results are presented in Figure 13.

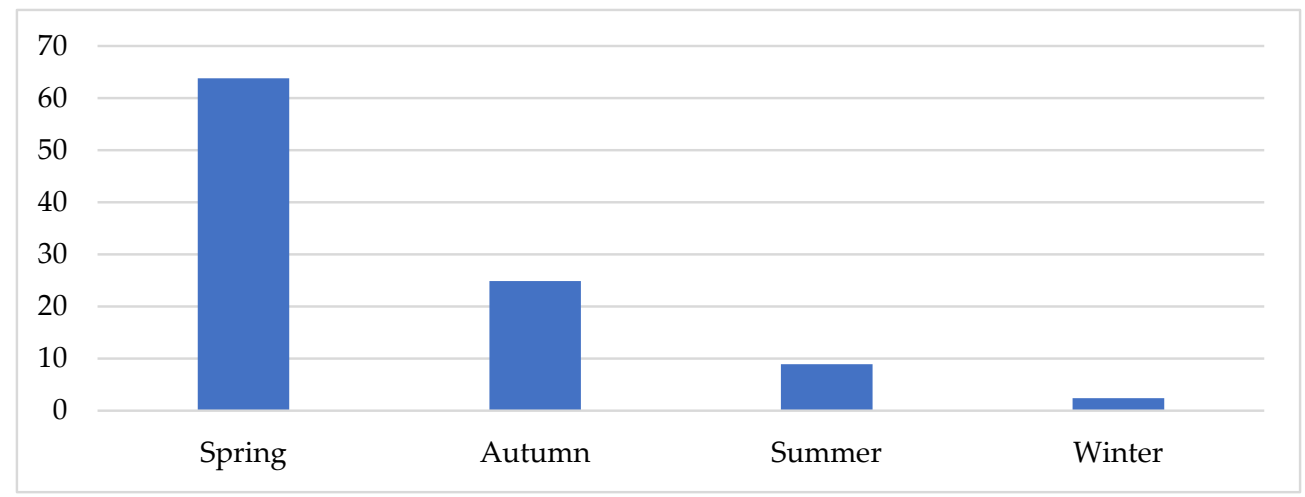

Figure 13. Opinion of the respondents about the most attractive season of the year in Tokyo in terms of tourism (\%).

Figure 13 demonstrates that the most attractive season of the year in Tokyo in terms of tourism is spring. The answer was marked by $2 / 3$ of the respondents. The second most-often selected response was autumn; $1 / 4$ of the respondents selected that response. The fewest respondents answered that winter was most attractive.

The respondents could justify why the season selected in the previous question was, according to them, the most attractive for tourism. The results are presented in Figure 14. 


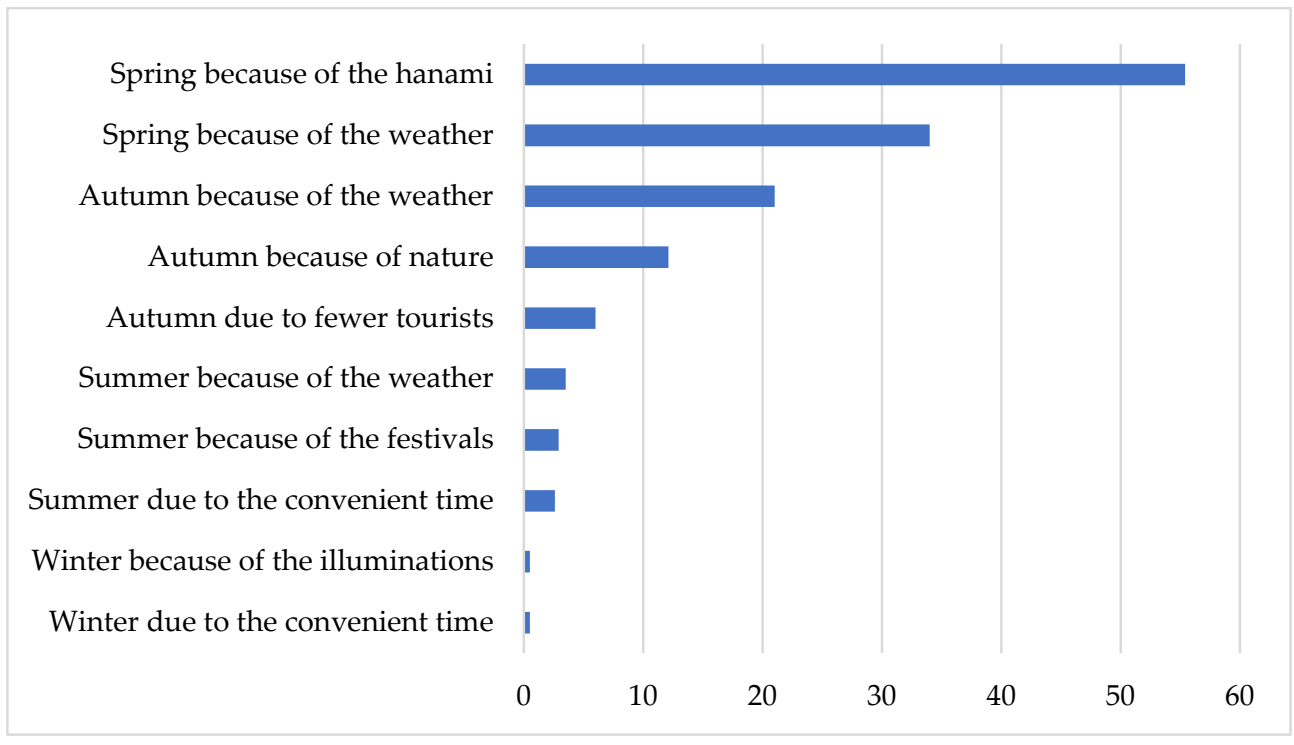

Figure 14. Justification of the selection of a given season of the year in terms of its attractiveness (\%). The respondent could indicate more than one response.

Many respondents justified their choice with more than one argument. The most frequent answer was that spring is most attractive because of hanami, namely the season of cherry blossoms. The selection of spring was also supported by the sightseeing weather, when it is not as hot as in summer, and when on most days it is sunny. Autumn was the second most eagerly selected season due to the right weather and discolouring of trees (mostly maple trees), namely the so-called momijigari, referred to as "the autumn equivalent of hanami". According to the respondents, in autumn in Tokyo, the number of tourists is lower, which allows for more relaxed sightseeing. Summer is rarely chosen due to the rainy season and hot weather, and winter-due to snow and frost.

A very important question was to investigate the opinions of the tourists about Tokyo's friendliness. The respondents could provide an answer about whether they consider Tokyo tourist friendly, and they could justify their choice (Figure 15).

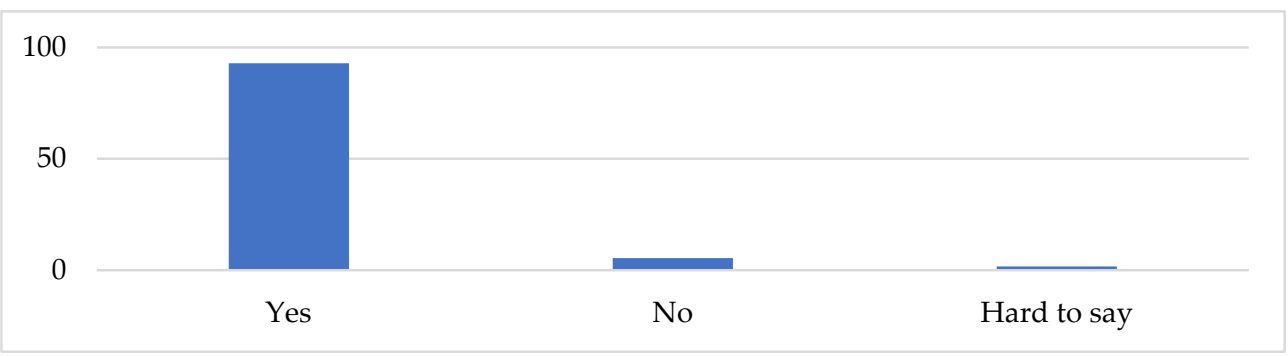

Figure 15. Opinion of the respondents about Tokyo as a tourist-friendly place (\%).

A definite majority of the respondents claimed that Tokyo is, in their opinion, tourist friendly. They justified their answers with the following arguments:

- Tokyo is a well-communicated city, and the residents of Tokyo are very nice and helpful;

- Tokyo is a very safe and well-signposted city; the city provides many interesting tourist attractions;

- Tokyo offers abundant accommodation; it is a city which is open to tourists and much information is offered in English.

The respondents who marked the answer "no" and "yes and no" most often supported their choice with: 
- The language barrier made their travel in Tokyo difficult;

- It is easy to get lost in the city;

- Tokyo is an expensive and very crowded city;

- People with no knowledge of the Japanese culture can experience so-called "cultural shock".

The same issue was compared with the age of the respondents (Figure 16).

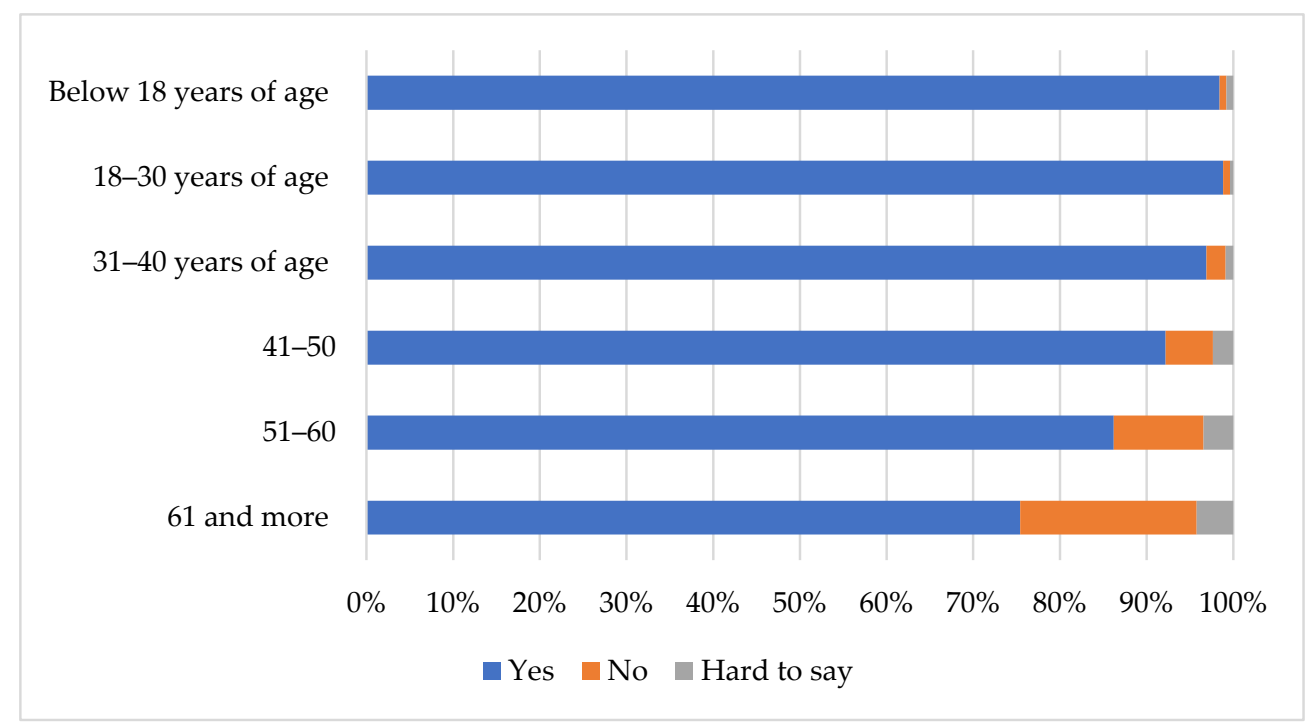

Figure 16. Opinion of the respondents about Tokyo as a tourist-friendly place depending on the age of the respondents $(\%)$.

The research shows that younger people more often positively assessed Tokyo as an attractive and friendly city than the elderly.

Tokyo is often considered a place where the residents do not speak English, and so the authors decided to investigate the respondents' opinions; see Figure 17.

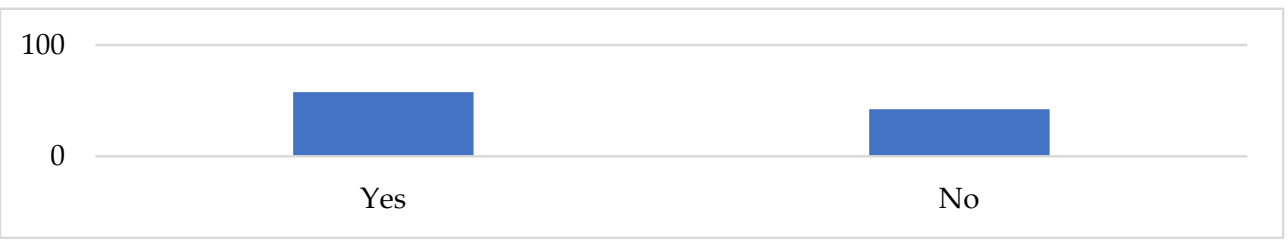

Figure 17. Problems with communicating in English in Tokyo according to the respondents (\%).

The figure shows that more than half of the respondents experienced a problem with communicating in English during their stay in Tokyo. However, the same high number of the respondents claimed not to have experienced such a problem. This may be thanks to the good preparation of the respondents to travel or to the fact that many people travelling to Tokyo know at least the basics of the Japanese language.

Yet another aspect covered in the study concerned the language barrier. The respondents evaluated here whether the language barrier can have a negative effect on the tourist attractiveness of Tokyo (Figure 18). 


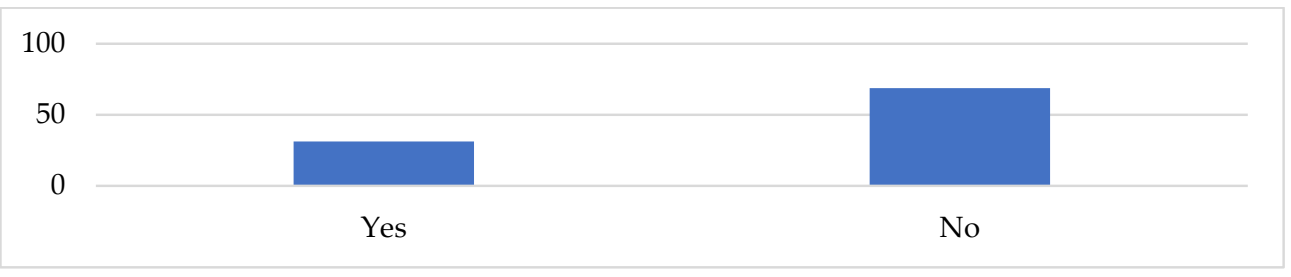

Figure 18. Opinion of the respondents on the impact of the language barrier on the tourist attractiveness of Tokyo (\%).

As one can note in the figure, more than $2 / 3$ of the respondents claimed that, in their opinion, the language barrier has no negative effect on the tourist attractiveness of Tokyo. However, almost $1 / 3$ of the respondents marked that it had a negative effect on the tourist attractiveness of the city, and this is quite a high percentage. One can thus state that Tokyo could attract many more tourists if it were not for the language barrier, which could be a problem for many people who do not speak Japanese.

The respondents could present their opinion on the respective elements of the tourist attractiveness of Tokyo. The results are presented in Table 3.

Table 3. Evaluation of elements of the tourist attractiveness of Tokyo in the opinion of the respondents.

\begin{tabular}{ccc}
\hline Elements of Tourist Attractiveness Evaluated & $\boldsymbol{N}=\mathbf{3 6 9}$ & Average Score \\
\hline Transport accessibility & 368 & 4.8 \\
Eating places & 367 & 4.8 \\
Cultural qualities & 367 & 4.7 \\
General tourist attractiveness & 369 & 4.6 \\
Accommodation & 363 & 4.6 \\
Accompanying infrastructure & 336 & 4.3 \\
Natural qualities & 367 & 3.9 \\
Price & 357 & 3.3 \\
\hline
\end{tabular}

As shown in the table, the highest scores were awarded to transport availability and eating places. Almost all the respondents evaluated those items. One can, therefore, claim that, according to the respondents, the transport availability in Tokyo is very high and traveling in the city is very easy and comfortable. The eating places can be considered well expanded and varied and the Japanese cuisine is an aspect which is very attractive for most of the respondents.

The lowest average score was awarded for the price. It is an important item to be considered while selecting the travel destination. The result suggests that Tokyo is quite an expensive destination for an average tourist, which can discourage any such trips. However, interestingly, it is a huge metropolis, and prices in big cities are usually higher than on the outskirts or in small locations/towns.

When travelling to Japan, people should remember the cultural and social differences. The authors of the article decided to ask the respondents what cultural and social differences they experienced during their stay in Tokyo (Figure 19). 
No waste bins in the streets

There are designated lines where we should line up for a train, subway or bus

It is not customary to tip

Removing shoes in some restaurants/Temples

Wearing masks by the Japanese (even before the COVID-19 pandemic)

It is forbidden to talk loudly on public transport

Prohibition of talking on the phone in public transport

No smoking in public spaces (except in designated places)

In most places in Tokyo, you can only pay with cash

Do not stick the sticks vertically into the rice

You can drink alcohol in public spaces

Tattoos are unwelcome

The Japanese don't like eye contact

It is not appropriate to put your feet on the threshold to make it easier to take off your..
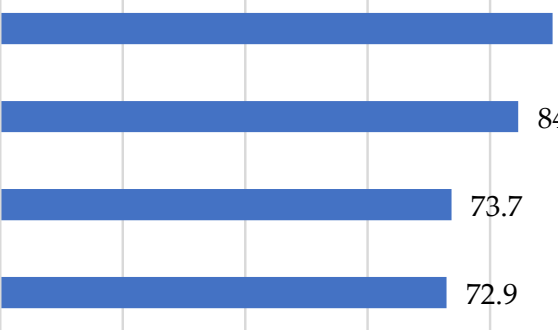

72.9

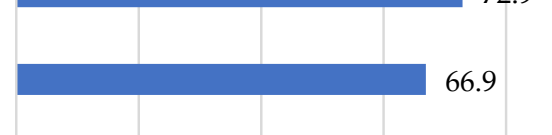

64.8

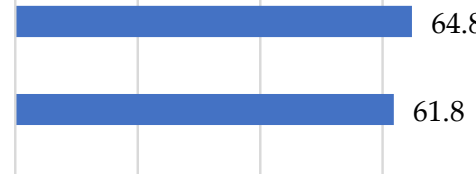

1.8

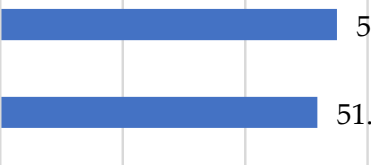

55

51.8

44.7

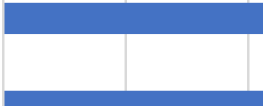

42.5

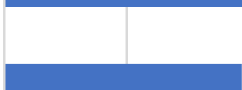

38.8

30.9

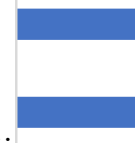

19.8

$0 \quad 20$

40

60

80

100

Figure 19. Cultural/social differences experienced by the respondents (\%). The respondent could indicate more than one answer.

A vast majority of the respondents noted a lack of rubbish bins in the streets. The streets in Tokyo are very clean and well-kept, albeit with no rubbish bins, which is quite a shock to the tourists. In Japan, much attention is given to rubbish sorting. You must take rubbish home, or where you stay, and sort it.

The next most often spotted difference was the lines along which one must queue up to the underground train, train or bus. Thanks to such a solution the city transport in Tokyo is very well organized and, despite the crowds, nobody pushes, which makes using public transport in such a big city as Tokyo convenient.

With the same frequency the respondents noted the fact that in Tokyo and all across Japan one does not give tips and that it is necessary to take off your shoes in some restaurants/temples. Tipping is indeed often considered disrespectful. It often is the case that tourists do not know about it and leave a tip, e.g., in the restaurant, and once the restaurant's personnel spots it, he or she follows the clients to give the money back.

Other differences indicated by a similar number of respondents are: 
- $\quad$ The Japanese people wearing face masks (even before the COVID-19 pandemic); the Japanese are very attentive not to infect others and so if they have a cold, they wear face masks;

- When taking public transport, one cannot talk loud; it is very important for tourists to know that having a loud conversation when on public transport is considered very bad manners;

- $\quad$ Talking on the phone when on public transport is forbidden; travelling in Tokyo as well as all across Japan, tourists should know that talking on the phone on public transport is forbidden and considered rude. So, if you do not want to offend the Japanese, you must turn the volume on a phone down before you enter public transport.

More than a half of the respondents noted two differences that must also be remembered while travelling in Tokyo:

- A ban on smoking in public spaces (except for designated places); it is a significant social difference for smokers, as when unaware of that difference, the tourist can receive a fine;

- In most places in Tokyo one can pay only with cash; although for the Olympics, cards started to be accepted as a payment method, while travelling in Tokyo and all across Japan, tourists should have cash on them. The difference can make travelling difficult as one has to look for ATMs to withdraw cash.

Least frequently, while staying in Tokyo, the respondents noted that it is not polite to put your feet on the doorstep to make it easier to take off your shoes. One can state, therefore, that to observe that difference, one must get to know the Japanese culture or most of the respondents had no opportunity to experience such a difference. The results suggest a lower significance of the difference, as compared with the previous ones.

The study also covered the impact of the above cultural and social differences on the tourist attractiveness of Tokyo. The respondents could choose from two responses: positive and negative (Figure 20).

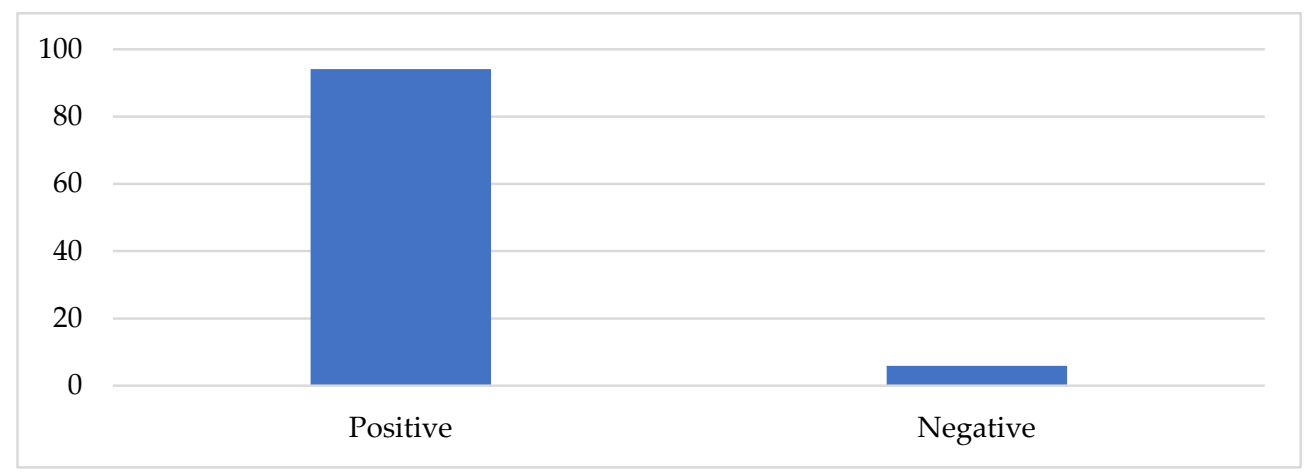

Figure 20. Evaluation of the effect of the above cultural and social differences on the tourist attractiveness of Tokyo (\%).

Analysing the figure, one can note that almost all the respondents agreed about the cultural and social differences enhancing the tourist attractiveness of Tokyo. One can, therefore, state that the cultural and social differences can attract tourists to Tokyo as being different and exotic. People are afraid of new things and, at the same time, they are curious about them and they want to experience them. Some differences can, however, cause some embarrassment, if one does not know about their existence and so, prior to a trip to Tokyo, it is worthwhile to read the articles or tourist guides about the city and the principles to be obeyed in it.

The question about cultural and social differences regarding the tourist attractiveness of Tokyo was compared with the education of the respondents. Detailed information is presented in Figure 21. 


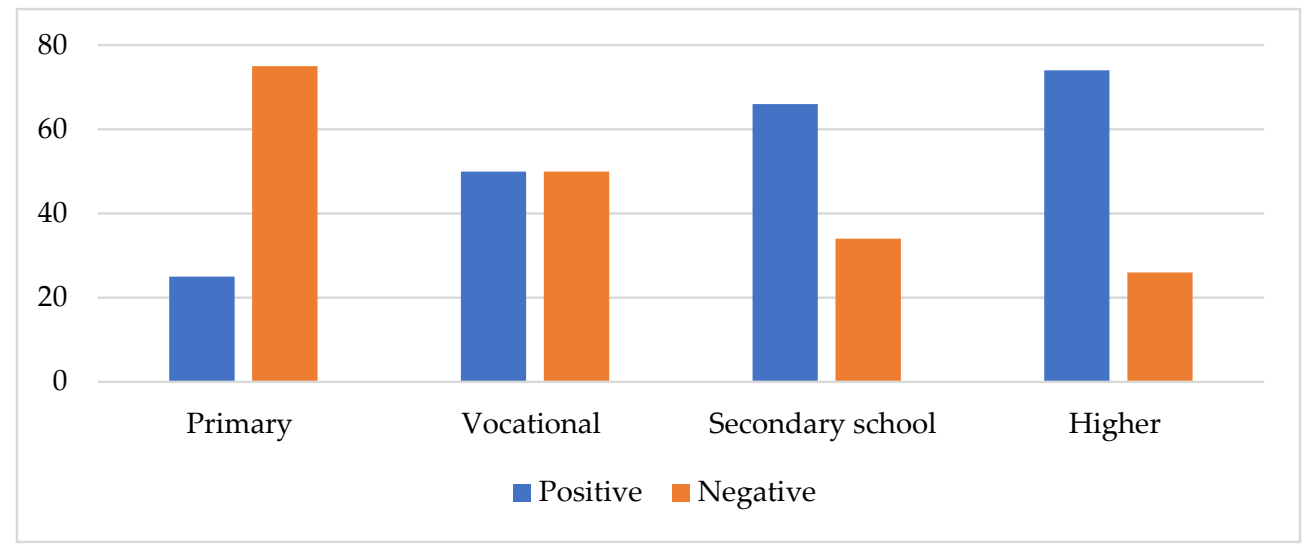

Figure 21. Evaluation of the effect of the above cultural and social differences on the tourist attractiveness of Tokyo depending on the education of the respondents (\%).

Respondents with higher education noticed Tokyo's increasing tourist attractiveness in terms of cultural differences. It can therefore be concluded that cultural and social differences can attract tourists to Tokyo.

\subsection{Historic Sites and Attractions Visited by Tourists in Tokyo}

The study presents some of the historic sites and attractions in Tokyo, and the persons surveyed could evaluate their tourist attractiveness by applying the 1-5 scale, where 1 stands for the lowest score and 5 for the highest score. The results are broken down in Table 4 in the form of the average score awarded by the respondents.

Table 4. Respondents' evaluation of the attractiveness of historic sites and places in Tokyo.

\begin{tabular}{ccc}
\hline Places Evaluated & $\mathbf{N = 3 6 9}$ & Average Score \\
\hline Sensō-ji temple & 312 & 4.4 \\
Shibuya district & 355 & 4.3 \\
Meiji temple & 310 & 4.3 \\
Shinjuku Gyoen & 277 & 4.3 \\
Shinjuku district & 350 & 4.2 \\
Park Ueno & 327 & 4.2 \\
Akihabara district & 341 & 4.1 \\
The National Museum in Tokyo & 177 & 4.1 \\
Edo-Tokyo Museum & 170 & 4.1 \\
Tokyo Skytree & 246 & 4.0 \\
Harajuku District & 327 & 3.9 \\
Tokyo Tower & 260 & 3.9 \\
Palace of the Emperor & 264 & 3.8 \\
\hline
\end{tabular}

The highest average score was awarded to the Sensō-ji temple, and a slightly lower average score to the Shibuya district, the Meiji temple, and the Shinjuku Gyoen park. The lowest average score was recorded for the Palace of the Emperor. The least frequently visited place was the Edo-Tokyo Museum, which was visited by less than half of the respondents.

Analysing all the results, it can be noted that, according to the respondents, the most attractive place was the Sensō-ji temple, and the least attractive place-the Palace of the Emperor. One must note, however, that the differences in scoring across many places were insignificant and the lowest score was still quite high. One can, therefore, claim that all those places are attractive for tourism and that each of them has something interesting to offer.

An important aspect covered in the study concerned other places visited by the respondents and those which they consider attractive. The respondents were welcome to provide their own suggestions (Figure 22). 


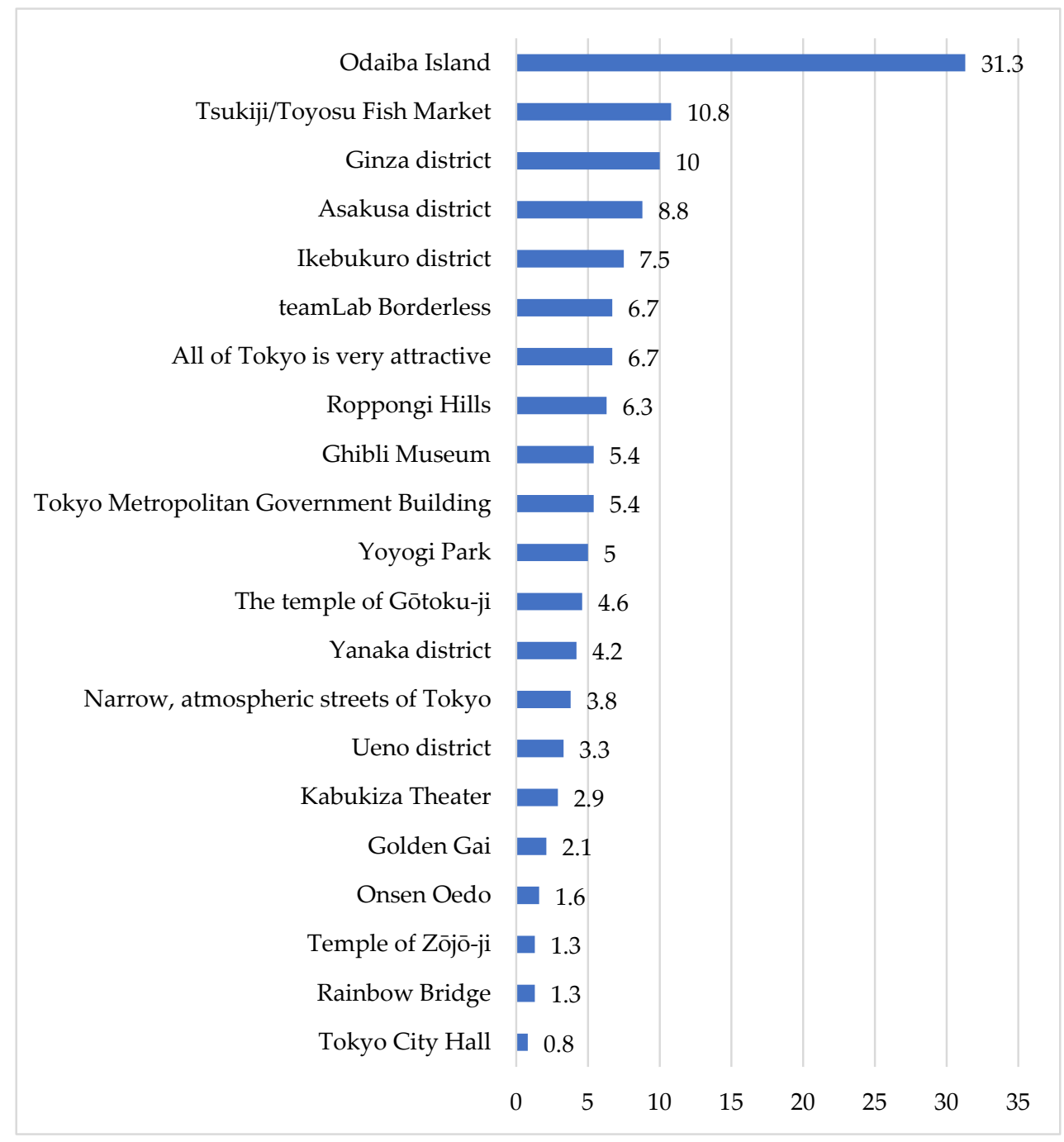

Figure 22. Other places considered attractive in terms of tourism in the opinion of the respondents (\%). The respondent could choose more than one response.

The most frequently mentioned place was the Odaiba island, indicated by, on average, $1 / 3$ of the respondents. Every tenth respondent pointed to the Tsukiji/Toyosu fish market and the Ginza district as places attractive for tourists. Interestingly, almost $7 \%$ of the respondents replied that, in their opinion, Tokyo is a place that is very attractive for tourists. An equally interesting observation can be how the respondents justified the choice of the Tokyo Metropolitan Government Building, pointed to by slightly over 5\%. The argument pointing to the attractiveness of the place is its good beauty spot which, unlike the popular Tokyo Skytree and Tokyo Tower, is free of charge.

\section{Discussion}

The tourist attractiveness of a specific place is an extremely important aspect, which has a huge impact on the tourist destination selection [44]. However, the article shows that it is very difficult to provide a univocal definition of tourist attractiveness, at least due to a variety of elements and factors affecting it. An essential question in considering that term is that each tourist has different expectations of the travel and of the destination. Of the same importance when evaluating the tourist attractiveness of a given place is to determine the form of tourism selected and the motivation behind the trip.

Table 5 presents scientific publications of selected authors presenting the subject of Tokyo's tourist attractiveness. 
Table 5. Scientific publications of selected authors presenting the tourist attractiveness of Tokyo.

\begin{tabular}{|c|c|c|c|}
\hline Authors & Title & Journal/Publishing & $\begin{array}{c}\text { Year of } \\
\text { Publication }\end{array}$ \\
\hline $\begin{array}{c}\text { Ranaweerage, Arima, Kikuchi } \\
\text { [45] }\end{array}$ & $\begin{array}{c}\text { Regional Characteristics of Urban Tourism in } \\
\text { Tokyo }\end{array}$ & Springer & 2018 \\
\hline Henderson [46] & Global cities, Tokyo, urban tourism & $\begin{array}{l}\text { International Journal of } \\
\text { Tourism Cities }\end{array}$ & 2017 \\
\hline Zhang, Xu, Lin, Lei [47] & $\begin{array}{l}\text { Cultural Capital and Destination Image of } \\
\text { Metropolitans: A Comparative Study of New York } \\
\text { and Tokyo Official Tourism Websites in Chinese }\end{array}$ & $\begin{array}{c}\text { Journal of China Tourism } \\
\text { Research }\end{array}$ & 2015 \\
\hline Ryu, Hyun, Shim [48] & $\begin{array}{c}\text { Creating New Relationships Through Tourism: A } \\
\text { Qualitative Analysis of Tourist Motivations of } \\
\text { Older Individuals in Japan }\end{array}$ & $\begin{array}{l}\text { Journal of Travel and } \\
\text { Tourism Marketing }\end{array}$ & 2015 \\
\hline Liou [49] & $\begin{array}{c}\text { Beyond Tokyo Rainbow Bridge: destination } \\
\text { images portrayed in Japanese drama affect } \\
\text { Taiwanese tourists' perception }\end{array}$ & $\begin{array}{l}\text { Journal of Vacation } \\
\text { Marketing }\end{array}$ & 2010 \\
\hline Saito, Matsui [50] & $\begin{array}{c}\text { Characteristics of Tourism in Tateyama: Tourist } \\
\text { Area in the Southern Region of the Tokyo } \\
\text { Metropolitan Area }\end{array}$ & $\begin{array}{l}\text { Tsukuba } \\
\text { Geoenvironmental } \\
\text { Sciences }\end{array}$ & 2009 \\
\hline
\end{tabular}

Source: [45-50].

The scientific publications presented in Table 5 show that the papers focus on the use of databases or other methods to develop the tools, demonstrating a variety of attractiveness in Tokyo. The authors use different variables to show the problem's complexity. Some authors determined the attractiveness in Tokyo with a comparative analysis and taxonomic methods, and some of them performed applicable survey studies.

According to Ranaweerage, Arima, and Kikuchi [45], Tokyo continues to thrive as a global destination for urban tourism. Tokyo's urban tourism destinations vary in attractiveness. Famous tourist destinations in Tokyo include Asakusa, Ginza, and Odaiba. Asakusa provides an insight into urban tourism dating back to the Edo period and its transformation to date. Ginza represents a contemporary case of urban tourism, dating back to the Meiji period, and Odaiba represents Tokyo's urban tourism in the 20th century.

Henderson [46] presents in his scientific publication a new look at the impact of global city status on tourism and the development of Tokyo as a destination that is usually overlooked in the literature. This author explored the relationship between global cities and international tourism, with particular emphasis on the recent experience of Tokyo, which has recently seen a significant increase in arrivals. It addresses questions about Tokyo's position as a global city and tourist destination.

Zhang, Xu, Lin, and Lei [47], by analysing the content of the official tourist websites of New York and Tokyo in Chinese, presented an innovative conceptual framework of cultural capital in relation to the image of a destination, recognizing different types of cultural capital in building the image of a destination. In their opinion, the cultural heritage constitutes the unique cultural personality of each metropolis, contributing to the shaping of an individual tourist image.

Ryu, Hyun, and Shim [48] examined the motivation of older Japanese people to travel. In the study, they used an open-ended survey and in-depth interviews to gain insight into building interpersonal relationships through tourism. Their results show that tourism is perceived as offering extraordinary opportunities to meet new people and forge and develop new relationships by older people in Japan, who experience fewer opportunities to interact with other people in their daily lives compared with those of younger generations.

Liou [49] believes that movies and TV shows provide intangible benefits to the local community or country, such as image enhancement or an increase in the level of awareness of a city. The authors of the article examined the impact of television series on increasing the popularity of traveling to Japan. 
Saito and Matsui [50] examined Tokyo's tourism resources, tourism dynamics, and tourism strategies. It was important to show the regional features of tourism in the southern metropolitan area of Tokyo.

The presented descriptions show that our questionnaire study can be compared with other questionnaire studies. They show that Tokyo is an attractive city for tourists. Most of the people surveyed travelled to Tokyo primarily for more than a week to visit the city's sights and attractions.

\section{Conclusions}

The objective of the article was to present the tourist attractiveness of Tokyo from a literature review and from the opinion of tourists who have visited the city at least once. A number of actions were taken to accomplish the objective:

- Basic information on Tokyo was studied;

- Tokyo accommodation facilities and eating places were presented;

- $\quad$ The key tourist attractions in Tokyo were demonstrated;

- Visitors to Tokyo were covered by a study;

- $\quad$ The research results were presented and interpreted.

The objective of the article was accomplished thanks to the study with a survey questionnaire. The research results presented in Figure 4 facilitate formulating the following conclusions:

- Transport availability is considered by the tourists as one of the best-operating elements of tourist attractiveness. Tokyo city transport is reliable and well expanded, which helps travelling.

- $\quad$ Eating places are definitely an element of tourist attractiveness, which is very much appreciated by tourists. Many eating places are very high quality, as seen from, e.g., the number of the eating facilities honoured with Michelin stars.

- Tokyo is a city with many interesting tourist attractions. Cultural assets are especially appreciated by the tourists due to the assets' variety and differences.

- Almost all of the tourists would like to visit Tokyo again, which demonstrates that it is a very attractive city.

- $\quad$ Tokyo is a very safe and tourist-friendly place. The residents are very nice and helpful.

- A tourist who does not speak Japanese can experience some discomfort while travelling in Tokyo as there is a lot of information that is not translated into English.

- The price is a factor that can discourage tourists from travelling to Tokyo. It is a city considered quite expensive.

The article assumes three hypotheses. The first hypothesis determined that the most attractive seasons of the year in Tokyo in terms of tourism are spring and autumn. The hypothesis was confirmed by the fact that, most frequently, the respondents marked that, in their opinion, spring and autumn are the most attractive seasons to visit Tokyo in, which is due to a convenient air temperature and friendly weather. Spring is also often chosen for its cherry blossom, and autumn for its discolouring trees and fewer tourists. The second hypothesis stated that the most attractive monument in Tokyo is the oldest Buddhist Sensō-ji temple, located in the Taitō district. The survey showed that, in the opinion of the respondents, the temple scored the highest. One must note, however, that the differences in scoring across many places were insignificant and the lowest score was still quite high. The third hypothesis was verified positively. The research shows that younger people more often positively assessed Tokyo as an attractive and friendly city than the elderly.

The article's coverage does not exhaust the subject of the tourist attractiveness of Tokyo in the opinion of tourists. It is a vast issue, affected by many constantly changing factors, very difficult to be fully verified. Tokyo is a city changing dynamically enough that it is hard to determine the way tourism will develop further in those areas. However, one can note that the Tokyo authorities are very attentive to and go to much effort for the development of the tourism sector in the city and for the growth of tourist attractiveness. 
To recapitulate, Tokyo can be considered a very attractive place for tourists, where every traveller can find something of interest. Tokyo amazes with its variety and difference and with the latest technological solutions, which are the cherry on the cake and which intermingle with the Japanese culture and tradition. The opinion of Polish tourists on the tourist attractiveness of Tokyo was high. This may be due to the fact that tourists more often perceive the tourist attractiveness of cities other than the cities they come from (where they live and where they grew up).

The issue presented in the article is new; it has not been examined. That is why the main aim was to use the authors' research. The organization of the concepts of tourism and the presentation of the COVID-19 pandemic's influence on tourism were new elements of the methodology in this article. The issues presented herein, in the authors' opinion, are new and have a considerable impact on the presentation of new trends in the development of tourism in the time of the COVID-19 pandemic. The issue discussed is very broad and the article does not exhaust it. Tourism in the time of the COVID-19 pandemic is observing dynamic changes [51-53]; therefore, following them and conducting similar research, e.g., into the influence of COVID-19 on the profitability of tourist businesses (hotels, motels, guesthouses, or agritourism farms) would be justified [54,55]. It is also necessary to conduct further research due to the fact that former research rarely focused on the influence of COVID-19 on tourism. It is probably necessary to conduct qualitative research in order to answer the questions:

- What is the influence of COVID-19 on the tourism labor market?

- Will COVID-19 lead to a radical transformation of the tourism sector?

- In what way can the tourism and hoteling sector respond to such changes in the future?

- How can the consequences of similar crises of public health be mitigated in the future?

Tokyo is the capital of the Land of the Rising Sun and a place where the kimono is worn on a daily basis, not only by representatives of the upper social classes and geisha. Thirtyfive million people live in Tokyo and 40 million in Poland as a whole. It is in Japan that karaoke was created, and the prices of accommodation and attractions do not change there depending on the tourist season. The tourist attractiveness of the city of Tokyo is of great importance to Polish tourists. The landmarks of Tokyo are diverse in character, ranging from sacred buildings to modern buildings expressing contemporary culture, for example. It is worth noting the atmosphere of ancient temples or seeing amazing sumo fights.

It is important to discuss the limitations of the study, which readers should consider when evaluating its results. The limitation of the research is the analysis itself, which focuses on the type of methods used, the scope of the research, and research trends in general. Another limitation in conducting the research is the proper selection of respondents in the times of the COVID-19 pandemic. Despite the limitations associated with the right choice of methods or respondents, it is argued that the presented topic deserves further empirical research by scientists studying the attitudes of residents and tourists to the development of Tokyo.

It is likely that the next waves of the COVID-19 pandemic will also cause variations in destination choices in 2022, including Tokyo. These variations will also be related to the introduction of restrictions on the use of tourist services by people who are not vaccinated against COVID-19.

Author Contributions: Conceptualization, M.R. and K.B.; methodology, M.R. and K.B.; software, M.R. and K.B.; validation, M.R. and K.B.; formal analysis, M.R. and K.B.; investigation, M.R. and K.B.; resources, M.R. and K.B.; data curation, M.R. and K.B.; writing—original draft preparation, M.R. and K.B.; writing—review and editing, M.R.; visualization, M.R.; supervision, M.R.; project administration, M.R.; funding acquisition, M.R. All authors have read and agreed to the published version of the manuscript.

Funding: This research received no external funding.

Institutional Review Board Statement: Not applicable. 
Informed Consent Statement: Not applicable.

Data Availability Statement: Not applicable.

Conflicts of Interest: The authors declare no conflict of interest.

\section{References}

1. Dopierała, K. Japonia (Japan); Bezdroża: Gliwice, Poland, 2020.

2. Available online: https://www.statista.com/statistics/914251/inbound-tourist-numbers-tokyo-japan/ (accessed on 22 February 2021).

3. Kruczek, Z. Atrakcje Turystyczne. Fenomen, Typologia, Metody Badań (Tourist Attractions. Phenomenon, Typology, Research Methods); Proksenia: Kraków, Poland, 2011.

4. Majewska, J.; Napierała, T.; Adamiak, M. Wykorzystanie nowych technologii i informacji do opisu przestrzeni turystycznej (The use of new technologies and information to describe tourism space). Folia Tur. 2016, 41, 309-338.

5. Krażewska, A.; Ossowska, L. Zróżnicowanie atrakcyjności turystycznej gmin nadmorskich w województwie zachodniopomorskim (Diversification of tourist attractiveness of seaside communes in the West Pomeranian Voivodeship). Zeszyty Naukowe Wydziału Nauk Ekonomicznych (Sci. J. Fac. Econ. Sci.) 2020, 24, 25-38.

6. Kruczek, Z. Polska. Geografia Atrakcji Turystycznych (Poland. Geography of Tourist Attractions); Proksenia: Kraków, Poland, 2011.

7. Batyk, I.M. Wpływ potencjału turystycznego na atrakcyjność turystyczną wybranych regionów Polski (Influence of the tourist potential on the tourist attractiveness of selected regions of Poland). Zeszyty Naukowe Uniwersytetu Szczecinskiego—Ekonomiczne Problemy Ustug (Sci. Pap. Univ. Szczec.-Econ. Probl. Serv.) 2010, 590, 52.

8. Bąk, I.; Matlegiewicz, M. Przestrzenne zróżnicowanie atrakcyjności turystycznej województw w Polsce w 2008 roku (Spatial differentiation of the tourist attractiveness of voivodships in Poland in 2008). Zeszyty Naukowe Uniwersytetu SzczecinskiegoEkonomiczne problemu ustug (Sci. J. Univ. Szczec.—Econ. Probl. Serv.) 2010, 590, 52.

9. Rapacz, A.; Jaremen, D.E. Atrakcyjność turystyczna jako czynnik wyboru destynacji turystycznej (Tourist attractiveness as a factor in choosing a tourist destination). Zeszyty Naukowe Uniwersytetu Szczecińskiego—Ekonomiczne Problemy Ustug (Sci. Pap. Univ. Szczec.-Econ. Probl. Serv.) 2011, 75, 131-141.

10. Bąk, I.; Szczecińska, B. Analiza atrakcyjności turystycznej miast wojewódzkich (Analysis of the tourist attractiveness of voivodeship cities). Wiadomości Statystyczne (Pol. Stat.) 2013, 12, 80-95.

11. Preisler, M. Uwarunkowania atrakcyjności turystycznej miasta (Determinants of tourist attractiveness of the city). Zeszyty Naukowe Wielkopolskiej Wyższej Szkoły Turystyki i Zarzadzania w Poznaniu (Sci. Pap. Greater Pol. Sch. Tour. Manag. Poznań) 2012, 8, 133-153.

12. Roman, M.; Roman, M.; Prus, P.; Szczepanek, M. Tourism Competitiveness of Rural Areas: Evidence from a Region in Poland. Agriculture 2020, 10, 569. [CrossRef]

13. Kowalczyk, A. Nowe formy turystyki miejskiej (New forms of urban tourism). Prace i Studia Geograficzne (Work. Geogr. Stud.) 2005, 35, 155-197.

14. Roman, M.; Gontarczyk, M.; Roman, M.; Kosiński, R.; Grudzień, P. Conditions for Choosing Form of Rest Agritourism from the Point of View of Respondents in Poland. Basrah J. Agric. Sci. 2020, 33, 14-27. [CrossRef]

15. Available online: https:/ / www.metro.tokyo.lg.jp/ENGLISH/ABOUT/HISTORY / history02.htm (accessed on 13 March 2021).

16. Available online: https://worldpopulationreview.com/world-cities/tokyo-population (accessed on 13 March 2021).

17. UNWTO/WTCF: City Tourism Performance Research. 2018. Available online: https://www.unwto.org/city-tourismperformance-research (accessed on 5 January 2022).

18. Available online: https://livejapan.com/en/in-tokyo/in-pref-tokyo/in-tokyo_suburbs/article-a0002533/ (accessed on 15 March 2021).

19. Matczak, A.; Szkup, R. Turystyczna baza noclegowa jako przedmiot analiz naukowych (Tourist accommodation as a subject of scientific analysis). In Turystyczna Baza Noclegowa Województwa Łódzkiego (Tourist Accommodation Base of the Lodzkie Voivodship); Szkup, R., Ed.; Uniwersytetu Łódzkiego: Łódź, Poland, 2020; Available online: https://dspace.uni.lodz.pl/xmlui/handle/11089/ 31481 (accessed on 5 January 2022).

20. Available online: https://www.japan-guide.com/e/e2025.html (accessed on 9 February 2021).

21. Available online: https://www.japan-guide.com/e/e2025_capsule_hotels.html (accessed on 9 February 2021).

22. Guichard-Anguis, S.; Moon, O. Japanese Tourism and Travel Culture; Routledge: Abingdon, UK, 2011; Available online: https: //www.routledge.com/Japanese-Tourism-and-Travel-Culture/Guichard-Anguis-Moon/p/book/9780415674461 (accessed on 5 January 2022).

23. Available online: https://www.japan-guide.com/e/e2026.html (accessed on 9 February 2021).

24. Redelman, M. Things to know and experience in Japan. AOFS Newsl. 2012, 4, 2-5.

25. Bureau of Industrial and Labor Affairs Tokyo Metropolitan Government. PRIME Tourist Destination City Tokyo. Tokyo Tourism Strategy Action Plan 2018; Tokyo Metropolitan Government: Tokyo, Japan, 2018; Available online: https:/ / www.sangyo-rodo. metro.tokyo.lg.jp/plan/tourism/pocket_total_2018en.pdf (accessed on 5 January 2022).

26. White Paper on Tourism in Japan, 2020 (Summary); Japan Tourism Agency: Tokyo, Japan, 2020; Available online: https:/ / www.mlit. go.jp/kankocho/en/siryou/content/001375676.pdf. (accessed on 5 January 2022). 
27. Stasiak, A. Gastronomia jako produkt turystyczny (Gastronomy as a tourist product). Turystyka i Hotelarstwo (Tour. Hosp.) 2007, 11, 103-132. Available online: https:/ / www.academia.edu/14373016/Gastronomia_jako_produkt_turystyczny_Gastronomy_ as_a_tourist_product (accessed on 5 January 2022).

28. Available online: https:/ / www.japan-guide.com/e/e3075.html (accessed on 16 February 2021).

29. Kuchnia Japońska (Japanese Cuisine); Biuletyn Informacyjny (Bulletin); Japanese Embassy in Tokyo: Tokyo, Japan, 2020.

30. Available online: https://www.afar.com/magazine/this-city-has-more-michelin-stars-than-any-other (accessed on 18 April 2021).

31. Walczak-Matla, P.; Matla, M. Japonia. Subiektywny Przewodnik Nieokrzesanego Gaijina (Japan. Subjective Guide of the Crude Gaijin); Pascal: Bielsko-Biała, Poland, 2020.

32. Available online: https:/ / www.byfood.com/blog/travel-tips/food-tourism-in-japan-japanese-food-infographic?fbclid=IwAR1 kINGwCcCLSrMSvcn8D8mqTiNbAga9_9j2S04zdF9vM2n65TJMmNp2L-0 (accessed on 17 February 2021).

33. Thompson, C.S. Host produced rural tourism: Towa's Tokyo Antenna Shop. Ann. Tour. Res. 2004, 31, 580-600. [CrossRef]

34. Number of Inbound Tourists to Tokyo, Japan from 2010 to 2019. Statista Research Department. 2020. Available online: https:/ / www.statista.com/statistics/914251/inbound-tourist-numbers-tokyo-japan/ (accessed on 5 January 2022).

35. Mimura, N.; Yasuhara, K.; Kawagoe, S.; Yokoki, H.; Kazam, S. Damage from the Great East Japan Earthquake and Tsunami-A Quick Report; Springer: Berlin/Heidelberg, Germany, 2011; Available online: https://tohoku.pure.elsevier.com/en/publications/ damage-from-the-great-east-japan-earthquake-and-tsunami-a-quick-r (accessed on 5 January 2022).

36. Sonnenberg, K. Tokio. Miasta Marzeń (Tokyo. Cities of Dreams); Agora: Warsaw, Poland, 2012; Available online: https://www.znak. com.pl/ksiazka/tokio-miasta-marzen-katarzyna-sonnenberg-22420 (accessed on 5 January 2022).

37. Drew, K.; Hallett, R.; Lee, O.; Zatko, M. The Rough Guide to Japan; Rough Guides: London, UK, 2020; Available online: https: //www.amazon.com/Rough-Guide-Japan-Guides/dp/1789195632 (accessed on 5 January 2022).

38. Gotowska, M. Introduction. In Cool Japan. Self-Presentation of Japan in Pop Culture; Wosińska, A., Ed.; Kirin: Bydgoszcz, Poland, 2017; Available online: https:/ / cyfroteka.pl/ebooki/Cool_Japan_Autoprezentacja_Japonii_w_popkulturze-ebook/p0203222 $3 \mathrm{i} 020$ (accessed on 5 January 2022).

39. Iwicka, R. Jak "Cool Japan" Zostało Zmyte Przez Hallyu-Zwiazki Soft Poweru Z Gospodarka ("Cool Japan" Was Washed Away by HallyuThe Soft Power Relationship with the Economy); Adam Marszałek: Torun, Poland, 2017; Available online: https: / / repozytorium.uwb. edu.pl/jspui/bitstream/11320/11083/1/Kultura_w_Polsce_XXI_wieku.pdf (accessed on 5 January 2022).

40. Williams, D. Tokyo 2020: A legacy or lethargy for tourism? Josai Int. Univ. Bull. Fac. Nurs. 2017, 25, 51-66.

41. Yamamura, E.; Tsutsui, Y. The Impact of Postponing 2020 Tokyo Olympics on the Happiness of O-MO-TE-NA-SHI Workers in Tourism: A Consequence of COVID-19. Sustainability 2020, 12, 8168. [CrossRef]

42. Boykoff, J.; Gaffney, C. The Tokyo 2020 Games and the End of Olympic History. Capital. Nat. Soc. 2020, 31, 1-19. [CrossRef]

43. Available online: https://www.businesswire.com/news/home/20161107005505/en/Launch-of-Japans-Largest-Promotionfor-Inbound-Tourism-from-Europe (accessed on 24 February 2021).

44. Gyunghoon, K.; Duffy, L.N.; DeWayne, M. Tourist attractiveness: Measuring residents' perception of tourists. J. Sustain. Tour. 2020, 28, 898-916. [CrossRef]

45. Ranaweerage, E.; Arima, T.; Kikuchi, T. Regional characteristics of urban tourism in Tokyo. In Tokyo as a Global City; International Perspectives in Geography (AJG Library); Kikuchi, T., Sugai, T., Eds.; Springer: Singapore, 2018. [CrossRef]

46. Henderson, J. Global cities, Tokyo, urban tourism. Int. J. Tour. Cities 2017, 3, 143-157. [CrossRef]

47. Zhang, H.; Xu, F.; Lin, L.; Lei, Y. Cultural Capital and Destination Image of Metropolitans: A Comparative Study of New York and Tokyo Official Tourism Websites in Chinese. J. China Tour. Res. 2015, 11, 121-149. [CrossRef]

48. Ryu, E.; Hyun, S.S.; Shim, C. Creating New Relationships Through Tourism: A Qualitative Analysis of Tourist Motivations of Older Individuals in Japan. J. Travel Tour. Mark. 2015, 32, 325-338. [CrossRef]

49. Liou, D.Y. Beyond Tokyo Rainbow Bridge: Destination images portrayed in Japanese drama affect Taiwanese tourists' perception. J. Vacat. Mark. 2010, 16, 5-15. [CrossRef]

50. Saito, J.; Matsui, K. Characteristics of Tourism in Tateyama: Tourist Area in the Southern Region of the Tokyo Metropolitan Area. Tsukuba Geoenviron. Sci. 2009, 5, 31-39.

51. Hoque, A.; Shikha, F.A.; Hasanat, M.W.; Arif, I.; Bakar, P.D.A.; Hamid, A. The Effect of Coronavirus (COVID-19) in the Tourism Industry in China. Asian J. Multidiscip. Stud. 2020, 3, 52-58.

52. Da Silva Lopes, H.; Remoaldo, P.C.; Ribeiro, V.; Martín-Vide, J. Effects of the COVID-19 Pandemic on Tourist Risk Perceptions-The Case Study of Porto. Sustainability 2021, 13, 6399. [CrossRef]

53. Roman, M.; Niedziółka, A.; Krasnodębski, A. Respondents' Involvement in Tourist Activities at the Time of the COVID-19 Pandemic. Sustainability 2020, 12, 9610. [CrossRef]

54. Lopes, H.S.; Remoaldo, P.C.; Ribeiro, V.; Martín-Vide, J. Perceptions of human thermal comfort in an urban tourism destination-A case study of Porto (Portugal). Build. Environ. 2021, 205, 108246. [CrossRef]

55. Roman, M.; Bhatta, K.; Roman, M.; Gautam, P. Socio-Economic Factors Influencing Travel Decision-Making of Poles and Nepalis during the COVID-19 Pandemic. Sustainability 2021, 13, 11468. [CrossRef] 